Gianmarco Daniele

Andrea F.M. Martinangeli

Francesco Passarelli

Willem Sas

Lisa Windsteiger

\title{
Fear and Loathing in Times of Distress \\ Causal Impact of Social and Economic Insecurity on Anti-Immigration Sentiment
}

Max Planck Institute for Tax Law and Public Finance Working Paper 2020 - 17

December 2020

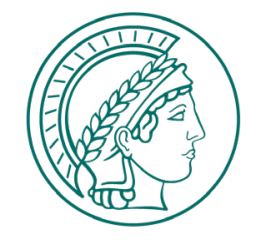

Max Planck Institute for Tax Law and Public Finance

Department of Business and Tax Law

Department of Public Economics

http:/ / www.tax.mpg.de 
Working papers of the Max Planck Institute for Tax Law and Public Finance Research Paper Series serve to disseminate the research results of work in progress prior to publication to encourage the exchange of ideas and academic debate. Inclusion of a paper in the Research Paper Series does not constitute publication and should not limit publication in any other venue. The preprints published by the Max Planck Institute for Tax Law and Public Finance represent the views of the respective author(s) and not of the Institute as a whole. Copyright remains with the author(s).

Max Planck Institute for Tax Law and Public Finance

Marstallplatz 1

D-80539 Munich

Tel: $\quad+498924246-0$

Fax: $\quad+498924246-501$

E-mail: ssrn@tax.mpg.de

http://www.tax.mpg.de 


\title{
Fear and Loathing in Times of Distress Causal Impact of Social and Economic Insecurity on Anti-Immigration Sentiment
}

\author{
Gianmarco Daniele* Andrea F.M. Martinangeli ${ }^{\dagger} \quad$ Francesco Passarelli ${ }^{\ddagger}$ \\ Willem Sas $^{\S} \quad$ Lisa Windsteiger ${ }^{\dagger}$
}

\begin{abstract}
The causal nexus between socio-economic stressors and anti-immigration sentiments remains unclear despite increasing evidence over their correlation. We exploit the social and economic disruptions brought about by the epidemic outbreak in March 2020 to randomly provide survey respondents with, at the time of the survey, pessimistic information about the economic and health consequences of the epidemic. Both economic and social stressors causally induce upsurges in anti-immigration sentiment and demand for fiscal pressure retrenchment. However, radicalised attitudes are accompanied by political radicalisation only when the negative economic consequences of the epidemic are highlighted.
\end{abstract}

JEL classification Codes: D72, H51, H53, H55, O52, P52

Keywords: economic crisis, social crisis, immigration, survey experiment, radical political preferences

Acknowledgments: We are extremely grateful to Simona Cicognani, Gloria Di Caprera, Gemma Dipoppa, Marco Le Moglie, Till Stowasser, Amedeo Piolatto and Laura Villalobos for excellent feedback and comments. Excellent research assistance was provided by Agnes Schelling.

We gratefully acknowledge generous financial support from the Max Planck Society.

Conflicting Interests: None

Ethics Clearance: Ethics Council of the Max Planck Society, Decision nr. 2020-15

Pre-Registration: AEARCTR-0005953

This draft: December 16, 2020.

${ }^{*}$ University of Milan and Bocconi University.

${ }^{\dagger}$ Max Planck Institute for Tax Law and Public Finance.

${ }^{\ddagger}$ University of Turin and Bocconi University

${ }^{\S}$ University of Stirling and KU Leuven 


\section{Introduction}

Immigration occupies a central and controversial position in the current socio-political and cultural debate (Alesina et al., 2018; Martinangeli and Windsteiger, 2019; Romarri, 2019; Guriev and Papaioannou, 2020). Despite immigrant populations contributing significantly to the growth of local economies and providing labour force to sectors with relatively scarce native offer, political parties and platforms endorsing anti-immigration positions have been ubiquitously on the rise (Turner and Cross, 2015). A fundamental political economic question is then the following : Should the ascent of the radical right be seen as the product of shocks to economic fundamentals rather than of changing social and cultural paradigms (Boeri, 2010; Polavieja, 2016; Kuntz et al., 2017; Dal Bo et al., 2018; Mutz, 2018; Norris and Inglehart, 2019; Fetzer, 2019)?

Instead of limiting the investigation to political preferences and other indirect expressions of nativism and xenophobia, this paper goes to the heart of the matter by investigating the role of economic and social shocks in driving mounting anti-immigration sentiments. By adopting a survey-experimental design, we isolate the impacts of the social and of the economic consequences of the Covid-19 crisis and show that both causally strengthen anti-immigration sentiments. However, we show that only the negative economic consequences causally translate into an increased probability of voting for xenophobic and populist parties.

We experimentally isolate the link between economic and social insecurity and antiimmigration sentiments from other cultural and economic conflicts typically motivating anti-immigrant, xenophobic and nativist attitudes by exploiting the exogenous and unexpected socio-economic shock represented by the Covid-19 pandemic outbreak in the first quarter of 2020. This strategy offers two main advantages: First, it is a truly exogenous and unanticipated natural disaster to the whole social and economic fabric, exposing individuals to unprecedented levels of economic insecurity (Daniele et al., 2020a; Fetzer et al., 2020). Second, precisely due to its "natural" origin, the consequences of the epidemic cannot credibly lend itself to the traditional anti-immigrant radical rhetoric (Mudde, 2007; Dal Bo et al., 2018; Fetzer, 2019).

We run our survey experiment in Italy (on a sample of 6014 individuals) ${ }^{1}$, one of the first among the European economies to experience the dramatic impact of the Covid-19 outbreak and among the hardest hit in terms of the consequent strain on its economy as

\footnotetext{
${ }^{1}$ According to the Italian government, in 2018 , immigrants represented $8.5 \%$ of the total population.
} 
well as on its health care system. Our design contrasts attitudes towards immigration in the socio-economic environment present in late May 2020 with a conservative estimate of those which would likely have been observed had the pandemic not occurred, or at least had a much weaker or negligible impact. In order to obtain the latter estimates, by definition unobservable by virtue of their counter-factual nature, we use the GDP projections for 2020 published by the OECD at the beginning of March. These projections allow us to expose a randomly selected group of our respondents to the (ex-post very optimistic) scenario in which the pandemic had virtually no effect on the economy $(-0.5 \%$ relative to 2019). ${ }^{2}$ We construct a comparison group by providing another portion of our sample with the far bleaker (and ex-post much more realistic) picture depicted by the Italian GDP projections published by Goldman-Sachs in early April 2020 (-11.2\% relative to 2019). ${ }^{3}$ We cannot and do not claim that the responses elicited from respondents provided with the optimistic OECD scenario actually are the ones that would have been observed had the pandemic truly had a limited impact. Nevertheless, their comparison with the responses under the dreary Goldman-Sachs scenario offers a lower bound for the difference between the attitudes measured under the current socio-economic environment in the late spring of 2020 and those that would have been measured had the crisis not taken place.

As argued in, for instance, Aassve et al. (2020) and Daniele et al. (2020a), the Covid19 epidemic is not only an economic crisis. It also is a stressor imposed on the social fabric itself with potentially long lasting effects on the organization of social life and on social capital. In order to gain insight into the specificities of the economic compared to non-economic impact of the crisis in driving anti-immigration sentiments, we complement our optimistic and pessimistic economic information conditions (henceforth referred to as investigating the economic dimension of the epidemic) with analogous information conditions which instead do not directly nor explicitly contain economic information. In doing so, we therefore focus on the other obvious dimension of the Covid-19 epidemic: that of health crisis (the health dimension of the epidemic). ${ }^{4}$

In particular, we provide our respondents with information about the difference be-

\footnotetext{
${ }^{2}$ Available at: http://www.oecd.org/economic-outlook/march-2020/

${ }^{3}$ See: https://www.ilsole24ore.com/art/dalla-crescita-zero-dell-ocse-meno-116percentogoldman-sachs-ecco-cosa-accadra-pil-italiano-2020-ADVObOK, and https://www.agi.it/ economia/news/2020-03-24/coronavirus-pil-italia-7817778/.

${ }^{4}$ Arguably, there are many more aspects of the crisis than the economic and health dimensions. We restrict this investigation to these two as we find them the most immediately salient to individuals and to keep the research design tractable.
} 
tween number of deaths expected since the onset of the epidemic in selected Italian cities and the number of deaths actually observed, reported by the Italian Ministry of Health. ${ }^{5}$ By selecting whether the information we provide concerns cities which experienced the greatest or the lowest relative discrepancy between expected and observed deaths, we are able to vary whether the health impact of the crisis is presented under a pessimistic or an optimistic light. Despite the economic and health information treatments not being directly comparable in terms of magnitude of their effects, we can safely evaluate the presence and the direction of their impacts on our sample's responses in search for qualitative similarities.

We find that under the pessimistic scenarios individuals are significantly more likely to declare current immigration levels as too high and significantly more likely to agree that public healthcare should prioritise Italians. In other words, making people aware of the harsh consequences of pandemic sharpens anti-immigration sentiments. We further find that the economic dimension of the crisis is the stronger, though not the sole driver of this effect. Experimentally induced pessimism about the health consequences of the epidemic also induces, albeit weaker, negative immigration sentiments. These findings mark a stark upsurge of anti-immigration sentiments in times of economic, but also more broadly social, hardship.

Moreover, we observe a significant increase in the probability of expressing political preferences for populist parties and explicitly nativist platforms once individuals' attention is focused on the negative economic consequences of the crisis. This effect is instead not borne out by pessimistic information in the health dimension.

We conclude that crisis awareness exasperates anti-immigration sentiments, an effect which is predominantly due to economic distress, but which also extends to other social stressors.

In what follows, Section 1.1 reviews the related literature, Section 2 describes our survey and the experimental design, Section 3 outlines our empirical strategy, Section 4 spells out the hypotheses, Section 5 presents the results and Section 6 discusses and concludes.

\footnotetext{
${ }^{5}$ Available here: www.deplazio.net/images/stories/SISMG/SISMG_Covid19.pdf.
} 


\subsection{Related literature}

Our paper is primarily related to the literature documenting the impact of economic conditions on socio-political attitudes. For instance, Guiso et al. (2017), Bellucci et al. (2019), Dehdari (2019) and Gidron and Mijs (2019) document an increased demand for radical right parties in connection with worsening economic circumstances. Fetzer (2019) shows that economic austerity in the United Kingdom radicalised political preferences to the point of by themselves causing the victory of the Leave camp in 2016 .

Other studies, primarily relying on correlational macro-evidence and often comparing attitudes across countries or time, have linked economic strain to upsurges in antiimmigration sentiments. The contraction of economic output and labour markets during the 2008 great recession has been correlated with increased anti-immigration sentiments (Polavieja, 2016; McGinnity and Kingston, 2017; Vogt Isaksen, 2019). Hatton (2016) finds that anti-immigrant sentiment is positively correlated with the share of social benefits in GDP and with the size of the immigrant population, but only weakly with unemployment rates, in times of recession.

Immigrant presence itself has also been observed to directly impact political preferences, causally determining the rise of radical political parties (Otto and Steinhardt, 2014; Barone et al., 2016; Halla et al., 2017; Harmon, 2018; Dustmann et al., 2019). Opposite findings are instead uncovered by Vertier et al. (2019), Gamalerio et al. (2020) and Steinmayr (2020).

\section{The Survey}

We hired the professional survey company Demetra to distribute the link to our survey to 6014 adults from the Italian resident population. ${ }^{6,7}$ We monitored the data collection in order to maximise the representativity of our sample with respect to geographic area of residence, age and gender. We moreover tried to achive a distribution of disposable equivalized household income as close as possible to the one provided by Eurostat. ${ }^{8}$ The survey was distributed during the first two weeks of June 2020. The English survey

\footnotetext{
${ }^{6}$ https://www.opinioni.net/

${ }^{7}$ We are a priori able to detect a minimum effect $\mathrm{MDE}=0.1$ on standardised outcome measures at $\alpha=0.05$ and power $\pi=0.8$ in comparison of optimist versus realistic/pessimistic information conditions in each of the economic and health conditions.

${ }^{8}$ EU-SILC: https://ec.europa.eu/eurostat/web/main/home
} 
questionnaire was translated to Italian by the native-speaking authors. ${ }^{9}$

The survey flow was structured as follows:

Background information Gender, age, marital status, household size (number of adults and number of children), household monthly disposable income (equivalized).

Information conditions The respondents randomly viewed one out of four information videos portraying either the economic or the health situation in Italy in an optimistic or in a pessimistic light. The information conditions are described in detail in Section 2.1 and in Appendix B. Immediately after having seen the information videos, the respondents were asked to restate the key information provided. This way we reinforce the manipulation by making sure that the information is taken in (the respondents could re-play the video any number of times).

Outcome questions We investigate the respondents' (anti-)immigration sentiments and perceived appropriateness of the tax burden in Italy. The list of outcome variables is reported in Table 1. The complete questionnaire is reported in Appendix A.

\begin{tabular}{ll}
\hline Core outcome variables & Label \\
The current level of immigration is too high & Too many immigrants \\
Public health services should be reserved to Italians & Health exp to natives \\
The general tax burden is too high & General tax burden \\
& \\
Voting outcomes & Label \\
Anti-immigrant vote intentions & Anti-immigrant voting \\
Populist vote intentions & Populism voting \\
Incumbent vote intentions & Incumbent voting
\end{tabular}

Table 1: List of outcome variables

Core outcome variables Our core outcome variables directly address our main research question: Do anti-immigration sentiments surge in times of socio-economic distress compared to times of relative stability? In order to answer such question, we ask our respondents to provide their answers to the following two questions: "On a scale from 1 to 10, do you think the current immigration level in your country is too low (1) or

\footnotetext{
${ }^{9}$ The English translation of the full questionnaire can be found in Appendix A. The interested reader can take the survey in Italian by using the following link https://taxmpg.eu.qualtrics.com/jfe/form/ SV_6LnKaH2XSJMs4Pb.
} 
too high (10)", and "On a scale from 1 to 10, how much do you think the public healthcare system in your country should prioritise Italians over immigrants? ( $1=$ not at all, $10=a$ lot)". The first question captures the respondents' general attitude towards immigration, while the second captures their attitudes towards immigration in connection with their usage of public health care resources. We feel that given the dual nature of the current crisis, economic as well as health, as discussed in Section 1 (Daniele et al., 2020a), such distinction is important to obtain a measure of individuals' general attitudes towards the immigration phenomenon untainted by the nature and causes of this particular crisis (an epidemic).

Moreover, we elicit the respondents' perception of the appropriateness of the economic size of the government via the following question: "On a scale from 1 to 10 , do you think the fiscal pressure in Italy is too low (1) or too high (10)?" Given the public character of healthcare in Italy and in light of the link established by previous literature between the size of the welfare state and anti-immigration attitudes (Hatton, 2016; Fetzer, 2019), we investigate whether our interventions cause a shift in individuals' preferred size of the government. Should this be the case, we would have an indication of a possible mechanism behind the nexus between the crisis and (anti-)immigration sentiments. ${ }^{10}$

Voting outcome variables The survey also includes a question on self-reported voting intentions. Specifically, we ask which party they would vote if the national elections were coming up next Sunday. We then construct a binary indicator of antiimmigrant political preferences identifying individuals who stated voting intentions for "Lega", "Fratelli d'Italia" and "Forza Italia". This classification of anti-immigrant parties is based on the Chapel Hill Expert Survey of 2017, which ranks parties on their immigrant policy (from strongly liberal to strongly restrictive). Using the same source, we construct a binary indicator of populist political preferences identifying individuals who stated voting intentions for "Lega", "Movimento 5 Stelle", "Fratelli d'Italia" and "Forza Italia". ${ }^{11}$ Finally, we identify respondents who state they would vote for the incumbent political parties, i.e. "Partito Demcratico" and "Movimento 5 Stelle".

\footnotetext{
${ }^{10}$ We additionally elicit perceptions of their own tax burden and the demand for tax-financed welfare state expenditure items to obtain a richer picture of the respondents' attitudes. These variables are discussed in Appendix C.3.

${ }^{11}$ In particular, we use the information coded in the "People vs. Elite" question, which asks the experts to evaluate the parties? position on direct vs. representative democracy issue on a scale going from 0 (i.e. Elected office holders should make the most important decisions) to 10 (i.e. "The people", not politicians, should make the most important decisions).
} 
Further demographic background information We elicit participants' highest educational attainment, employment status and immigration background.

Debriefing At the end of the survey, respondents reached a debriefing screen. There, they received complementary information to the one they had received during the survey as part of the experimental manipulation. Respondents in the economic conditions were told that many agencies release GDP forecasts, one of which being the one they were given during the survey, and were then given the one they did not receive. Likewise for the health conditions. This way we ensure that no respondent was left with a distorted picture of the current economic and health situation in Italy.

\section{$2.1 \quad$ Experimental conditions}

Our respondents were assigned to four non-overlapping groups, each of which was exposed to only one of the four information conditions. The information was provided by means of short information videos directly on the respondents' screen. ${ }^{12}$

Economic dimension In the economic dimension we varied whether our respondents received overly optimistic or overly pessimistic (ex-post, realistic) outlooks about the Italian economy for the year 2020.

Pessimistic economic condition The respondent was given information about the projected GDP drop (-11.2\%) computed in April by Goldman-Sachs for 2020. To allow the respondent to get a better feeling of the meaning of such information, it was placed in relation to and compared with the GDP drop experienced by the Italian economy in 2009 as consequence of the financial crisis $(-5.7 \%)$. These pieces of information were provided both in words and graphically.

Optimistic economic condition The respondent was given information about the projected GDP drop (-0.5\%) computed in February by the OECD for 2020. As in the pessimistic condition, this information was placed provided in comparison with the GDP drop in 2009 (-5.7\%). Again, these pieces of information were provided both in words and graphically.

\footnotetext{
${ }^{12}$ The information provided and links to the videos can be found in Appendix B.
} 
Health dimension In the health dimension we varied whether the respondent received pessimistic or optimistic information about the incidence of the epidemic in selected Italian cities.

Pessimistic health condition In this condition, we informed respondents about the difference (in percentage terms) between the number of expected deaths based on the previous five years and the number actually observed since the onset of the epidemic in selected Italian cities. In particular, we showed participants that in some Italian cities, the actually observed number of deaths had been much higher since the beginning of the epidemic (Aosta, $+126 \%$, and Brescia, $+195 \%$ ) than the expected number of deaths forecast by the Ministry of Health (based on the actual number of deaths observed in the same period in the previous five years), and that a similarly large difference in actual compared to expected deaths had been observed in many other Italian cities. The city names were omitted from the information videos to avoid inducing territorial primes in the respondents.

Optimistic health condition In this condition, we informed respondents about the difference (in percentage terms) between the number of expected deaths based on the previous five years and the number actually observed since the onset of the epidemic in selected Italian cities. In particular, we informed participants that in some Italian cities the difference between the expected and observed number of deaths was small (Rome, $+5 \%$, and Palermo, $+2 \%$ ), and that a similarly small difference in actual compared to expected number of deaths had been observed in many other Italian cities. Also in this case the city names were omitted to avoid inducing territorial priming.

\section{Analysis and statistical methods}

We investigate individuals' responses to our survey in search for systematic differences between those who received optimistic and pessimistic scenarios, separately for the economic and health dimensions. The different nature of the two scenarios and the straightforward interpretation of differences within a given dimension across optimistic and realistic/pessimistic information warrant that the two dimensions be analysed and interpreted separately in empirical investigations.

Let Pess $\in\{0,1\}$ take value 1 if the respondent received pessimistic information 
and 0 otherwise. For each of our outcome variables and within the economic and health dimensions, we then estimate the following OLS regression:

$$
Y=\beta_{0}+\beta_{1} \text { Pess }+\beta_{2} X+\beta_{3} W+\beta_{4} R+\varepsilon
$$

where $Y$ is our vector of outcome variables, $X, R$, and $W$ are vectors of respectively individual, regional and provincial controls. The list of control variables is reported in Table $2 .{ }^{13}$ Standard errors are clustered at the province level. Finally, we standardise our outcome variables with respect to the optimistic groups within each dimension. For this reason, regression coefficients for the impact of pessimistic information in the economic (health) dimension should be interpreted in terms of the standard deviation of the responses of the optimistic economic (health) group.

\begin{tabular}{ll}
\hline Variable vector & Variable \\
& Employment status \\
& College degree or higher \\
& Italian native \\
Gender (female=1) & Age (5 classes) \\
& Family size \\
& Sample income tertile \\
& Marital status (single=1) \\
& Population size \\
Provincial controls: $W$ & Immigrant population share \\
& Per capita GDP (GDP p.c.) \\
& Unemployment rate \\
& Life expectancy \\
& Per capita cumul. \# of Covid-19 \\
& new cases at survey launch (C19) \\
\hline
\end{tabular}

Table 2: List of control variables by type

\footnotetext{
${ }^{13}$ Table C1 in Appendix C.1 shows that our sample is balanced across our information conditions and dimensions.
} 


\section{Hypotheses}

We rely on previous evidence correlating economic and social crises with (anti-)immigration sentiment to draw hypotheses about the direction of our estimates. In particular, recent investigations (for instance: Dehdari (2019), Gidron and Mijs (2019), Vogt Isaksen (2019)) all find positive correlations between exposure to economic instability and political preferences in favour of radical right-wing parties or personal attitudes towards immigration. We therefore expect exposure to the pessimistic (and ex-post realistic) projections for the Italian GDP released by Goldman Sachs to increase our respondents' level of agreement with both our anti-immigration outcome variables, compared to respondents who received the optimistic forecast:

Hypothesis 1. Anti-immigration sentiments are reinforced by the presentation of pessimistic economic forecasts compared to optimistic ones.

The expected impact of optimism or pessimism in the health domain is less clear. On the one hand, the presentation of a pessimistic health scenario might cause antiimmigration sentiments to be more pronounced in an analogous reasoning to that formulated for the economic dimension. A pessimistic outlook concerning the epidemic's health impact implies that also the economy will suffer dramatically, therefore GDP will go down a lot and less resources will be available to finance the welfare state. Hence, the pie is smaller and sharing it with immigrants is seen as more of a burden. In addition, severe health consequences of the epidemic imply that the health system will be under a lot of strain and thus providing health care also for immigrants might be regarded as taking away resources from natives. A pessimistic scenario concerning the epidemic's health impact might thus make respondents less in favour of publicly provided health care for immigrants. On the other hand, the population might be more accepting of extending public health services to immigrant populations in the pessimistic health scenario. Experiencing an epidemic, in which the average level of public health is more likely to impact one's own, might allow individuals to recognise the importance of providing timely and adequate health care to everyone. Precisely to capture this ambivalent effect, we included the question eliciting individuals' attitudes towards immigrants' usage of public healthcare services. Our second hypothesis therefore distinguishes between health related and non-health related anti-immigration sentiments: 


\section{Hypothesis 2.}

a. General anti-immigration sentiments are strengthened by the presentation of a pessimistic picture of the health situation compared to an optimistic one.

b. Health-related anti-immigration sentiments could be strengthened or weakened by the presentation of a pessimistic picture of the health situation compared to an optimistic one.

\section{$5 \quad$ Experimental results}

We now present the main results of our analyses. Within each dimension, we compare the impact of receiving pessimistic (or ex-post realistic) compared to optimistic information using OLS regressions. Appendix E reports the results of corrections of our estimations for multiple hypothesis testing. We control for respondents' individual characteristics and covariates at the regional and provincial levels as explained above. We cluster standard errors at the province level. ${ }^{14}$

We begin by investigating the impact of pessimism in the economic dimension in comparison to the optimistic scenario. Table 3 reports the coefficients from the estimation of model (1) for our immigration and perceptions of the general tax burden outcome variables.

\footnotetext{
${ }^{14}$ Notice that because of the different nature of the information provided and the lack of a common reference framework across the two dimensions, comparison of attitudes across equally pessimistic or optimistic information across dimensions is meaningless.
} 
Table 3: OLS regression of immigration sentiments: economic dimension

\begin{tabular}{|c|c|c|c|}
\hline \multirow[b]{2}{*}{ VARIABLES } & \multicolumn{3}{|c|}{$\begin{array}{l}\text { Economic dimension } \\
\end{array}$} \\
\hline & Too many immigrants & Health exp to natives & General tax burden \\
\hline \multirow[t]{2}{*}{ Pessimistic info. } & $0.112^{* * *}$ & $0.101^{* * *}$ & $0.068^{* *}$ \\
\hline & $(0.035)$ & $(0.031)$ & $(0.032)$ \\
\hline \multirow[t]{2}{*}{ Unemployed } & $0.138^{* *}$ & -0.034 & 0.087 \\
\hline & $(0.067)$ & $(0.066)$ & $(0.066)$ \\
\hline \multirow[t]{2}{*}{ College } & $-0.251^{* * *}$ & $-0.188^{* * *}$ & -0.055 \\
\hline & $(0.037)$ & $(0.034)$ & $(0.037)$ \\
\hline \multirow[t]{2}{*}{ Female } & $0.135^{* * *}$ & $0.077^{* *}$ & -0.035 \\
\hline & $(0.034)$ & $(0.036)$ & $(0.033)$ \\
\hline \multirow[t]{2}{*}{ Income tertile $=2$} & -0.074 & $-0.102^{* *}$ & 0.027 \\
\hline & $(0.049)$ & $(0.051)$ & $(0.044)$ \\
\hline \multirow[t]{2}{*}{ Income tertile $=3$} & -0.053 & -0.085 & -0.029 \\
\hline & $(0.051)$ & $(0.056)$ & $(0.053)$ \\
\hline \multirow[t]{2}{*}{ GDP p.c. } & 0.003 & 0.001 & $0.013^{*}$ \\
\hline & $(0.007)$ & $(0.007)$ & $(0.007)$ \\
\hline \multirow[t]{2}{*}{ Unemployment (\% 15-64) } & $0.022^{*}$ & $0.025^{* *}$ & $0.031^{* * *}$ \\
\hline & $(0.012)$ & $(0.012)$ & $(0.010)$ \\
\hline \multirow[t]{2}{*}{ C19 } & 5.643 & $24.773^{*}$ & -15.682 \\
\hline & $(12.725)$ & $(13.142)$ & $(13.587)$ \\
\hline \multirow[t]{2}{*}{ Immigrant pop. ( $\%$ prov.) } & 0.015 & 0.025 & -0.025 \\
\hline & $(0.023)$ & $(0.025)$ & $(0.026)$ \\
\hline \multirow[t]{2}{*}{ Constant } & $-11.135^{* *}$ & -9.240 & $-9.693^{* *}$ \\
\hline & $(5.036)$ & $(6.931)$ & $(3.725)$ \\
\hline \multicolumn{4}{|l|}{ Omitted controls: } \\
\hline - Individual & $\checkmark$ & $\checkmark$ & $\checkmark$ \\
\hline - Regional & $\checkmark$ & $\checkmark$ & $\checkmark$ \\
\hline - Provincial & $\checkmark$ & $\checkmark$ & $\checkmark$ \\
\hline Observations & 3,003 & 3,003 & 3,003 \\
\hline R-squared & 0.051 & 0.039 & 0.043 \\
\hline
\end{tabular}

The table displays the results form OLS regressions of our immigration sentiment and tax burden outcomes on our pessimistic economic information intervention. Omitted individual controls: age, family size, italian born, single. Omitted regional controls: life expectancy. Omitted provincial controls: population.

Robust standard errors, clustered at province level, in parentheses. $* * * \mathrm{p}<0.01,{ }^{* *} \mathrm{p}<0.05,{ }^{*} \mathrm{p}<0.1$

We find strong and significant positive effects on our immigration attitudes questions. Specifically, agreement with the statement that immigration is too high increases in the economic pessimism group by $11.2 \%(\mathrm{p}=0.002)$ of the optimistic group's standard deviation. A similar effect can be observed concerning agreement with the statement that public healthcare should be reserved to natives $(+10.1 \%$ of the optimistic economic group standard deviation, $\mathrm{p}=0.002)$.

Further, we find that perceptions about the excess of the tax burden in Italy also 
increases among those who receive pessimistic economic information $(+6.8 \%$ of the optimistic economic group, $\mathrm{p}=0.031$ ).

We summarise the findings about immigration sentiment in Result 1:

Result 1. Pessimism in the economic dimension has a strengthening impact on general and health-care-related anti-immigration sentiments, and on perceptions of the tax burden as excessive.

Next, we turn to the impact of pessimism in the health dimension. Table 4 reports the results from the estimation of model (1) on data collected from respondents in the health dimension. At a first glance we can see that the effects move in the same direction but are smaller and less significant than in the economic dimension. In particular, we find that pessimism does not strengthen general anti-immigration sentiments $(+5.5 \%$ of the health pessimism group's standard deviation, $\mathrm{p}=0.159)$, but significantly increases anti-immigration sentiments in the health domain $(+7 \%, \mathrm{p}=0.050)$. 
Table 4: OLS regression of immigration sentiments: health dimension

\begin{tabular}{|c|c|c|c|}
\hline \multirow[b]{2}{*}{ VARIABLES } & \multicolumn{3}{|c|}{ Health dimension } \\
\hline & Too many immigrants & Health exp to natives & General tax burden \\
\hline \multirow[t]{2}{*}{ Pessimistic info. } & 0.055 & $0.071^{* *}$ & -0.028 \\
\hline & $(0.039)$ & $(0.036)$ & $(0.040)$ \\
\hline \multirow[t]{2}{*}{ Unemployed } & 0.029 & -0.014 & 0.067 \\
\hline & $(0.067)$ & $(0.065)$ & $(0.062)$ \\
\hline \multirow[t]{2}{*}{ College } & $-0.216^{* * *}$ & $-0.148^{* * *}$ & $-0.087^{*}$ \\
\hline & $(0.038)$ & $(0.039)$ & $(0.047)$ \\
\hline \multirow[t]{2}{*}{ Female } & $0.187^{* * *}$ & $0.105^{* * *}$ & -0.027 \\
\hline & $(0.035)$ & $(0.040)$ & $(0.039)$ \\
\hline \multirow[t]{2}{*}{ Income tertile $=2$} & $-0.123^{* * *}$ & $-0.089 * *$ & -0.011 \\
\hline & $(0.042)$ & $(0.043)$ & $(0.050)$ \\
\hline \multirow{2}{*}{ Income tertile $=3$} & $-0.229 * * *$ & $-0.131^{* * *}$ & -0.085 \\
\hline & $(0.042)$ & $(0.044)$ & $(0.058)$ \\
\hline \multirow[t]{2}{*}{ GDP p.c. } & 0.003 & 0.001 & -0.006 \\
\hline & $(0.008)$ & $(0.008)$ & $(0.011)$ \\
\hline \multirow[t]{2}{*}{ Unemployment (\% 15-64) } & 0.013 & 0.011 & -0.010 \\
\hline & $(0.015)$ & $(0.012)$ & $(0.018)$ \\
\hline \multirow[t]{2}{*}{ C19 } & 1.199 & -7.330 & -3.704 \\
\hline & $(13.748)$ & $(13.968)$ & $(18.019)$ \\
\hline \multirow[t]{2}{*}{ Immigrant pop. ( $\%$ prov.) } & -0.015 & 0.023 & 0.002 \\
\hline & $(0.025)$ & $(0.026)$ & $(0.033)$ \\
\hline \multirow[t]{2}{*}{ Constant } & -7.613 & $-11.465^{* *}$ & -2.012 \\
\hline & $(5.706)$ & $(4.399)$ & $(5.646)$ \\
\hline \multicolumn{4}{|l|}{ Omitted controls: } \\
\hline - Individual & $\checkmark$ & $\checkmark$ & $\checkmark$ \\
\hline - Regional & $\checkmark$ & $\checkmark$ & $\checkmark$ \\
\hline - Provincial & $\checkmark$ & $\checkmark$ & $\checkmark$ \\
\hline Observations & 2,956 & 2,956 & 2,956 \\
\hline R-squared & 0.059 & 0.059 & 0.038 \\
\hline
\end{tabular}

The table displays the results form OLS regressions of our immigration sentiment and tax burden outcomes on our pessimistic health information intervention. Omitted individual controls: age, family size, italian born, single. Omitted regional controls: life expectancy. Omitted provincial controls: population.

Robust standard errors, clustered at province level, in parentheses. $* * * \mathrm{p}<0.01, * * \mathrm{p}<0.05, * \mathrm{p}<0.1$

On the contrary, perceived excessiveness of the general tax burden remains instead unaffected $(-2.8 \%, \mathrm{p}=0.486)$ by the presentation of pessimistic information.

We summarise these findings in Result 2 :

Result 2. Pessimism regarding the consequences of the pandemic on public health strengthens health-care-related anti-immigration sentiments, while general anti-immigration sentiments and perceptions of the tax burden are unaffected. 


\subsection{Shifts in political preferences}

We now show that the impact of our intervention is not limited to anti-immigration sentiments. Rather, our results underpin a broader shift in our respondents' political preferences in line with what was observed by previous research. An increasing number of studies have recently documented how the success of radical parties promoting antiimmigrant and nativist agendas is often associated with both economic and socio-cultural instability (e.g. Dehdari (2019); Dustmann et al. (2019)). It is argued that these parties' success can be ascribed to their supporters' discontent with immigration, globalization and economic and technological change potentially leading to wage and job loss (Dehdari, 2019). Two competing arguments can be made in this sense. First, the Covid-19 crisis is, to all effects, a natural disaster which cannot be attributed credibly to any of the social groups against which traditional populist rhetoric is focused (e.g. immigrants, political actors and financial elites as in (Mudde, 2007; Dal Bo et al., 2018; Fetzer, 2019)). In other words, fear and economic anxiety originating from the current crisis can hardly be channelled via radicalization of one's political preferences along the usual lines (Daniele et al., 2020a). On the other hand, radical political parties often actively or passively capture individuals' broadly defined socio-economic anxiety. For these reasons we might expect to observe either a negligible impact on individuals' political preferences or to find evidence for increased support for radical parties in response to receiving pessimistic information about the consequences of the crisis.

We consider the three outcomes presented in Section 2, i.e. voting preferences for anti-immigrant, populist and incumbent parties. We then model the probability of expressing voting preferences falling in one of our three classes as a function of the type of information received, controlling for all the covariates listed in Table 2 using probit models (standard errors are clustered at province level). Notice that the constellation of common and not common membership of the different political parties to our classifications allow us to safely capture the different attraction of the anti-immigration rhetoric, platforms and programmes from more broadly populist ones.

Tables 5 and 6 display the results of the estimation of linear probability models for voting intentions supporting anti-immigration, radical (populist) and incumbent parties. ${ }^{15}$ The evidence in Table 5 corroborates and reinforces our findings summarised in

\footnotetext{
${ }^{15}$ Appendix C.2 reports results from analogous estimations of probit models, all confirming the results here reported.
} 
Result 1: We observe significant shifts towards anti-immigrant and populist platforms once individuals are exposed to pessimistic information about the Italian economic outlook. This finding is aligned with, for instance, Dehdari (2019), who finds vote shares for radical parties to increase in response to increased worker layoffs.

Table 5: OLS regression of voting intentions: economic dimension

\begin{tabular}{|c|c|c|c|}
\hline \multirow[b]{2}{*}{ VARIABLES } & \multicolumn{3}{|c|}{ Economic dimension } \\
\hline & Anti-immigration & Populism & Incumbent \\
\hline \multirow[t]{2}{*}{ Pessimistic info. $=1$} & $0.031^{*}$ & $0.030^{*}$ & -0.009 \\
\hline & $(0.017)$ & $(0.016)$ & $(0.017)$ \\
\hline \multirow[t]{2}{*}{ Unemployed } & -0.005 & 0.003 & -0.009 \\
\hline & $(0.029)$ & $(0.030)$ & $(0.036)$ \\
\hline \multirow[t]{2}{*}{ College } & $-0.033^{* *}$ & $-0.090 * * *$ & 0.016 \\
\hline & $(0.015)$ & $(0.017)$ & $(0.018)$ \\
\hline \multirow[t]{2}{*}{ Female } & 0.013 & -0.025 & $-0.033^{*}$ \\
\hline & $(0.019)$ & $(0.020)$ & $(0.018)$ \\
\hline \multirow[t]{2}{*}{ Income tertile $=2$} & 0.013 & -0.001 & 0.039 \\
\hline & $(0.027)$ & $(0.026)$ & $(0.024)$ \\
\hline \multirow[t]{2}{*}{ Income tertile $=3$} & 0.004 & -0.030 & $0.085^{* * *}$ \\
\hline & $(0.019)$ & $(0.026)$ & $(0.021)$ \\
\hline \multirow[t]{2}{*}{ GDP p.c. } & $0.008^{* *}$ & 0.006 & -0.005 \\
\hline & $(0.003)$ & $(0.004)$ & $(0.004)$ \\
\hline \multirow[t]{2}{*}{ Unemployment (\% 15-64) } & $0.010^{*}$ & $0.015^{* *}$ & -0.006 \\
\hline & $(0.005)$ & $(0.006)$ & $(0.007)$ \\
\hline \multirow[t]{2}{*}{ C19 } & -6.500 & -9.206 & -0.402 \\
\hline & $(6.603)$ & $(7.312)$ & $(8.117)$ \\
\hline \multirow[t]{2}{*}{ Immigrant pop. ( $\%$ prov.) } & -0.012 & 0.005 & 0.022 \\
\hline & $(0.011)$ & $(0.013)$ & $(0.016)$ \\
\hline \multirow[t]{2}{*}{ Constant } & $-8.112^{* * *}$ & $-3.728^{*}$ & $6.820^{* * *}$ \\
\hline & $(2.076)$ & $(2.179)$ & $(2.589)$ \\
\hline \multicolumn{4}{|l|}{ Omitted controls: } \\
\hline - Individual & $\checkmark$ & $\checkmark$ & $\checkmark$ \\
\hline - Regional & $\checkmark$ & $\checkmark$ & $\checkmark$ \\
\hline - Provincial & $\checkmark$ & $\checkmark$ & $\checkmark$ \\
\hline Observations & 3,003 & 3,003 & 3,003 \\
\hline R-squared & 0.041 & 0.029 & 0.031 \\
\hline
\end{tabular}

Robust standard errors in parentheses

$$
\text { *** } \mathrm{p}<0.01,{ }^{*} * \mathrm{p}<0.05,{ }^{*} \mathrm{p}<0.1
$$

The table displays the results form OLS regressions of voting intentions on our pessimistic economic information intervention. Omitted individual controls: age, family size, italian born, single. Omitted regional controls: life expectancy. Omitted provincial controls: population.

Robust standard errors, clustered at province level, in parentheses.

$* * * \mathrm{p}<0.01,{ }^{* *} \mathrm{p}<0.05,{ }^{*} \mathrm{p}<0.1$

The same result does not emerge from the investigation of the health dimension in 
Figure 6. Here, receiving pessimistic information about the health related consequences of the epidemic does not cause any significant shifts towards populist platforms or antiimmigration parties.

Table 6: OLS regression of voting intentions: health dimension

\begin{tabular}{|c|c|c|c|}
\hline \multirow[b]{2}{*}{ VARIABLES } & \multicolumn{3}{|c|}{$\begin{array}{l}\text { Health dimension } \\
\end{array}$} \\
\hline & Anti-immigration & Populism & Incumbent \\
\hline \multirow[t]{2}{*}{ Pessimistic info. $=1$} & 0.000 & -0.014 & -0.023 \\
\hline & $(0.017)$ & $(0.018)$ & $(0.014)$ \\
\hline \multirow[t]{2}{*}{ Unemployed } & 0.004 & -0.013 & $-0.072^{* * *}$ \\
\hline & $(0.027)$ & $(0.030)$ & $(0.026)$ \\
\hline \multirow[t]{2}{*}{ College } & $-0.069^{* * *}$ & $-0.084^{* * *}$ & $0.066^{* *}$ \\
\hline & $(0.019)$ & $(0.021)$ & $(0.026)$ \\
\hline \multirow[t]{2}{*}{ Female } & -0.011 & $-0.043^{* *}$ & $-0.047^{* *}$ \\
\hline & $(0.017)$ & $(0.018)$ & $(0.019)$ \\
\hline \multirow[t]{2}{*}{ Income tertile $=2$} & 0.018 & 0.010 & 0.037 \\
\hline & $(0.019)$ & $(0.025)$ & $(0.026)$ \\
\hline \multirow[t]{2}{*}{ Income tertile $=3$} & 0.001 & -0.025 & $0.068^{* *}$ \\
\hline & $(0.022)$ & $(0.026)$ & $(0.030)$ \\
\hline \multirow[t]{2}{*}{ GDP p.c. } & $0.008^{* *}$ & 0.005 & $-0.007^{*}$ \\
\hline & $(0.004)$ & $(0.004)$ & $(0.004)$ \\
\hline \multirow[t]{2}{*}{ Unemployment (\% 15-64) } & 0.009 & $0.017^{* *}$ & -0.002 \\
\hline & $(0.008)$ & $(0.007)$ & $(0.008)$ \\
\hline \multirow[t]{2}{*}{ C19 } & 1.509 & 4.458 & 5.640 \\
\hline & $(6.524)$ & $(7.157)$ & $(6.539)$ \\
\hline \multirow[t]{2}{*}{ Immigrant pop. ( $\%$ prov.) } & -0.011 & -0.023 & 0.003 \\
\hline & $(0.013)$ & $(0.014)$ & $(0.012)$ \\
\hline \multirow[t]{2}{*}{ Constant } & -2.661 & -0.495 & 3.664 \\
\hline & $(2.784)$ & $(2.552)$ & $(3.174)$ \\
\hline \multicolumn{4}{|l|}{ Omitted controls: } \\
\hline - Individual & $\checkmark$ & $\checkmark$ & $\checkmark$ \\
\hline - Regional & $\checkmark$ & $\checkmark$ & $\checkmark$ \\
\hline - Provincial & $\checkmark$ & $\checkmark$ & $\checkmark$ \\
\hline Observations & 2,956 & 2,956 & 2,956 \\
\hline R-squared & 0.048 & 0.044 & 0.045 \\
\hline
\end{tabular}

The table displays the results form OLS regressions of voting intentions on our pessimistic health information intervention. Omitted individual controls: age, family size, italian born, single. Omitted regional controls: life expectancy. Omitted provincial controls: population.

Robust standard errors, clustered at province level, in parentheses.

$* * * \mathrm{p}<0.01, * * \mathrm{p}<0.05, * \mathrm{p}<0.1$

We therefore confirm that the radicalisation of political preferences is a phenomenon tightly linked to economic insecurity, even when the traditional rhetoric and arguments 
of radical parties cannot credibly target those social segments against which the discourse is commonly addressed. The findings for the economic and health conditions in Tables 5 and 6 are consistent with Daniele et al. (2020a). ${ }^{16}$ They find evidence for two competing impacts of the Covid-19 crisis, each brought about, respectively, by the economic and health/social dimensions of the epidemic. In the first case, increased economic anxiety causes sizeable drops in trust towards politicians and sharpens dissatisfaction with the governing institution, while the same is instead not true in the second.

\subsection{Heterogeneity analysis: Share of immigrant population}

In this section, we investigate whether our interventions have heterogeneous effects to the share represented by immigrants in the respondent's province of residence. We investigate further heterogeneous effects with respect to respondents' income bracket, exposure to the virus and the incidence of the epidemic in their region in Appendix D.

We interact the indicator for having received pessimistic information with the share of immigrants in the respondent's region of residence. In other words we estimate the following variation of model (1) with an interest in coefficient $\beta_{3}$ :

$$
\begin{aligned}
Y= & \beta_{0}+\beta_{1} \text { Pess }+\beta_{2} \% \text { Imm }+\beta_{3}[\text { Pess } \times \% \text { Imm }]+ \\
& +\beta_{4} X+\beta_{5} W+\beta_{6} R+\beta_{7}[\text { Pess } \times \text { p.c.GDP }]+\varepsilon .
\end{aligned}
$$

In addition to the individual and regional controls included in the regressions for Tables 3 and 4, we now control for the interaction between the indicator for having received pessimistic information and per capita GDP of the respondent's region of residence. Including this interaction term allows us control for any additional heterogeneous effects of our pessimistic information with respect to regional GDP. This exercise is performed separately for the economic (Table 7) and the health (Table 8) dimensions.

From Table 7, we see that the impact of the pessimistic economic outlook seems to be mitigated in provinces with a higher immigrant presence. Notice that the linear impact of our pessimistic economic information in this estimation remains positive and strongly significant, consistently with the results presented in Table 3. This finding is consistent with Steinmayr (2020) and points towards a mitigating effect of contact with immigrant

\footnotetext{
${ }^{16}$ See also: "Covid-19 and socio-political attitudes in Europe: In competence we trust.", VoxEU/CEPR policy portal (Daniele et al., 2020b).
} 
populations on anti-immigration sentiments. Notice further that also for health-related immigration concerns and perceptions of the general tax burden the linear terms for our economic intervention are consistent with the effects reported in Table 3.

Table 7: OLS regression of immigration sentiments: economic dimension

\begin{tabular}{|c|c|c|c|}
\hline \multirow[b]{2}{*}{ VARIABLES } & \multicolumn{3}{|c|}{ Economic dimension } \\
\hline & Too many immigrants & Health exp to natives & General tax burden \\
\hline \multirow[t]{2}{*}{ Pessimistic info. } & 0.028 & -0.121 & -0.105 \\
\hline & $(0.138)$ & $(0.108)$ & $(0.125)$ \\
\hline \multirow[t]{2}{*}{ Immigrant pop. ( $\%$ prov.) } & 0.027 & 0.036 & -0.014 \\
\hline & $(0.025)$ & $(0.026)$ & $(0.027)$ \\
\hline \multirow[t]{2}{*}{ Pess. info. $\times$ Imm. pop. ( $\%$ prov. $)$} & $-0.026^{* *}$ & $-0.021^{*}$ & $-0.023^{*}$ \\
\hline & $(0.013)$ & $(0.011)$ & $(0.012)$ \\
\hline \multirow[t]{2}{*}{ Unemployed } & $0.136^{* *}$ & -0.039 & 0.084 \\
\hline & $(0.067)$ & $(0.067)$ & $(0.066)$ \\
\hline \multirow[t]{2}{*}{ College } & $-0.250 * * *$ & $-0.187^{* * *}$ & -0.054 \\
\hline & $(0.037)$ & $(0.034)$ & $(0.037)$ \\
\hline \multirow[t]{2}{*}{ Female } & $0.135^{* * *}$ & $0.077^{* *}$ & -0.035 \\
\hline & $(0.034)$ & $(0.036)$ & $(0.033)$ \\
\hline \multirow{2}{*}{ Income tertile $=2$} & -0.075 & $-0.104^{* *}$ & 0.025 \\
\hline & $(0.049)$ & $(0.051)$ & $(0.044)$ \\
\hline \multirow[t]{2}{*}{ Income tertile $=3$} & -0.053 & -0.086 & -0.030 \\
\hline & $(0.052)$ & $(0.056)$ & $(0.053)$ \\
\hline \multirow[t]{2}{*}{ GDP p.c. } & 0.002 & -0.002 & 0.011 \\
\hline & $(0.007)$ & $(0.007)$ & $(0.007)$ \\
\hline \multirow[t]{2}{*}{ Unemployment (\% 15-64) } & $0.022^{*}$ & $0.025^{* *}$ & $0.032^{* * *}$ \\
\hline & $(0.012)$ & $(0.012)$ & $(0.010)$ \\
\hline \multirow[t]{2}{*}{ C19 } & 5.804 & $25.159^{*}$ & -15.376 \\
\hline & $(12.726)$ & $(13.104)$ & $(13.527)$ \\
\hline \multirow[t]{2}{*}{ Pess. info. $\times$ GDP p.c. } & 0.002 & $0.006^{* *}$ & 0.005 \\
\hline & $(0.003)$ & $(0.003)$ & $(0.003)$ \\
\hline \multirow[t]{2}{*}{ Constant } & $-11.129^{* *}$ & -9.254 & $-9.699^{* *}$ \\
\hline & $(5.044)$ & $(6.934)$ & $(3.722)$ \\
\hline \multicolumn{4}{|l|}{ Omitted controls: } \\
\hline - Individual & $\checkmark$ & $\checkmark$ & $\checkmark$ \\
\hline - Regional & $\checkmark$ & $\checkmark$ & $\checkmark$ \\
\hline - Provincial & $\checkmark$ & $\checkmark$ & $\checkmark$ \\
\hline Observations & 3,003 & 3,003 & 3,003 \\
\hline R-squared & 0.051 & 0.040 & 0.044 \\
\hline
\end{tabular}

The table displays the results form OLS regressions of our immigration sentiment and tax burden outcomes on our pessimistic economic information intervention interacted with the share represented by the immigrant population in the respondents' region of residence. Omitted individual controls: age, family size, italian born, single. Omitted regional controls: life expectancy. Omitted provincial controls: population. The regression also controls for the interaction between per capita regional GDP and the indicator for having received pessimistic information.

Robust standard errors, clustered at province level, in parentheses.

$* * * \mathrm{p}<0.01, * * \mathrm{p}<0.05, * \mathrm{p}<0.1$ 
A different picture emerges from Table 8. There, we see that the impact of our pessimistic health information on general and health-related anti-immigration sentiments does not vary across provinces with different immigrant population shares. Again, the linear terms in the estimation are consistent with the coefficients reported in Figure 4. On the contrary, the impact of our pessimistic health scenario on perceptions of the general tax burden as being excessive is substantially mitigated by a larger share of the immigrant population in the respondents' province of residence. 
Table 8: OLS regression of immigration sentiments: health dimension

\begin{tabular}{|c|c|c|c|}
\hline \multirow[b]{2}{*}{ VARIABLES } & \multicolumn{3}{|c|}{ Health dimension } \\
\hline & Too many immigrants & Health exp to natives & General tax burden \\
\hline \multirow[t]{2}{*}{ Pessimistic info. } & 0.109 & -0.000 & -0.010 \\
\hline & $(0.137)$ & $(0.139)$ & $(0.154)$ \\
\hline \multirow[t]{2}{*}{ Immigrant pop. (\% prov.) } & -0.014 & 0.028 & 0.026 \\
\hline & $(0.028)$ & $(0.028)$ & $(0.033)$ \\
\hline \multirow[t]{2}{*}{ Pess. info. $\times$ Imm. pop. ( $\%$ prov.) } & -0.003 & -0.010 & $-0.049^{* * *}$ \\
\hline & $(0.017)$ & $(0.014)$ & $(0.018)$ \\
\hline \multirow[t]{2}{*}{ Unemployed } & 0.028 & -0.014 & 0.066 \\
\hline & $(0.067)$ & $(0.065)$ & $(0.062)$ \\
\hline \multirow[t]{2}{*}{ College } & $-0.216^{* * *}$ & $-0.148^{* * *}$ & $-0.087^{*}$ \\
\hline & $(0.038)$ & $(0.039)$ & $(0.047)$ \\
\hline \multirow[t]{2}{*}{ Female } & $0.187^{* * *}$ & $0.105^{* * *}$ & -0.027 \\
\hline & $(0.035)$ & $(0.040)$ & $(0.039)$ \\
\hline \multirow[t]{2}{*}{ Income tertile $=2$} & $-0.122^{* * *}$ & $-0.089^{* *}$ & -0.009 \\
\hline & $(0.042)$ & $(0.043)$ & $(0.050)$ \\
\hline \multirow{2}{*}{ Income tertile $=3$} & $-0.228 * * *$ & $-0.133^{* * *}$ & -0.084 \\
\hline & $(0.042)$ & $(0.044)$ & $(0.058)$ \\
\hline \multirow[t]{2}{*}{ GDP p.c. } & 0.003 & 0.000 & -0.006 \\
\hline & $(0.008)$ & $(0.008)$ & $(0.011)$ \\
\hline \multirow[t]{2}{*}{ Unemployment (\% 15-64) } & 0.013 & 0.011 & -0.011 \\
\hline & $(0.015)$ & $(0.012)$ & $(0.018)$ \\
\hline \multirow[t]{2}{*}{ C19 } & 1.238 & -7.385 & -3.705 \\
\hline & $(13.705)$ & $(13.960)$ & $(18.069)$ \\
\hline \multirow[t]{2}{*}{ Pess. info. $\times$ GDP p.c. } & -0.001 & 0.002 & 0.000 \\
\hline & $(0.004)$ & $(0.004)$ & $(0.004)$ \\
\hline \multirow[t]{2}{*}{ Constant } & -7.659 & $-11.401^{* *}$ & -2.011 \\
\hline & $(5.698)$ & $(4.407)$ & $(5.660)$ \\
\hline \multicolumn{4}{|l|}{ Omitted controls: } \\
\hline - Individual & $\checkmark$ & $\checkmark$ & $\checkmark$ \\
\hline - Regional & $\checkmark$ & $\checkmark$ & $\checkmark$ \\
\hline - Provincial & $\checkmark$ & $\checkmark$ & $\checkmark$ \\
\hline Observations & 2,956 & 2,956 & 2,956 \\
\hline R-squared & 0.059 & 0.059 & 0.039 \\
\hline
\end{tabular}

The table displays the results form OLS regressions of our immigration sentiment and tax burden outcomes on our pessimistic health information intervention interacted with the share represented by the immigrant population in the respondents' region of residence. Omitted individual controls: age, family size, italian born, single. Omitted regional controls: life expectancy. Omitted provincial controls: population. The regression also controls for the interaction between per capita regional GDP and the indicator for having received pessimistic information.

Robust standard errors, clustered at province level, in parentheses.

$* * * \mathrm{p}<0.01,{ }^{* *} \mathrm{p}<0.05,{ }^{*} \mathrm{p}<0.1$ 


\section{Conclusions}

The past two decades have witnessed a surge in both migration flows on one hand and nativism and support for radical right parties with less than inclusive political agendas on the other (Dal Bo et al., 2018; Bellucci et al., 2019; Dustmann et al., 2019). Literature in economics and other social sciences have researched their co-dynamics in search for the deep drivers of anti-immigration sentiments. Despite the positive correlation between social and economic insecurity and anti-immigration attitudes emerging from previous studies, the causal nexus has remained, so far, poorly understood. We provide evidence that not only economic, but also non-economic social distress cause an upsurge in antiimmigration sentiments.

We exploit the social and economic crisis brought about by the outbreak of the Covid-19 epidemic to design experimental interventions allowing us to randomly induce optimistic or pessimistic perceptions of the crisis. In particular, we randomly provide our respondents with pessimistic or overly optimistic forecasts about the epidemic's impact on the Italian economy during the first way of the epidemic in June 2020.

We find that, indeed, pessimistic information about the economic impact of the pandemic significantly strengthens both direct and indirect (as vote intentions for explicitly anti-immigrant and populist political platforms) expressions of anti-immigration sentiments. A similar result, though weaker, is obtained through the random distribution of optimistic and pessimistic information about the health (as opposed to economic) effects of the crisis. These attitude shifts are accompanied by a stark increase in the perception that the country's fiscal burden is excessive.

\section{References}

Aassve, A., Alfani, G., Gandolfi, F., and Moglie, M. L. (2020). Pandemics and social capital: From the Spanish flu of 1918-19 to COVID-19. VoxEU.

Alesina, A., Miano, A., and Stantcheva, S. (2018). Immigration and Redistribution. Working Paper 24733, National Bureau of Economic Research.

Barone, G., D'Ignazio, A., de Blasio, G., and Naticchioni, P. (2016). Mr. Rossi, Mr. Hu and politics. The role of immigration in shaping natives' voting behavior. Journal of Public Economics, 136:1-13. 
Barsbai, T., Licuanan, V., Steinmayr, A., Tiongson, E., and Yang, D. (2020). Information and the formation of social networks. NBER Working paper 27346.

Bellucci, D., Conzo, P., and Zotti, R. (2019). PERCEIVED IMMIGRATION AND VOTING BEHAVIOR. ESt Working paper series 15/19.

Boeri, T. (2010). Immigration to the Land of Redistribution. Economica, 77(308):651-687. _eprint: https://onlinelibrary.wiley.com/doi/pdf/10.1111/j.14680335.2010.00859.x.

Dal Bo, E., Finan, F., Folke, O., Persson, T., and Rickne, J. (2018). Economic Losers and Political Winners: Sweden's Radical Right. mimeo, page 64.

Daniele, G., Martinangeli, A. F., Passarelli, F., Sas, W., and Windsteiger, L. (2020a). Wind of Change? Experimental Survey Evidence on the Covid-19 Shock and SocioPolitical Attitudes in Europe. SSRN Scholarly Paper ID 3671674, Social Science Research Network, Rochester, NY.

Daniele, G., Martinangeli, A. F. M., Passarelli, F., Sas, W., and Windsteiger, L. (2020b). Covid-19 and socio-political attitudes in Europe: In competence we trust. VoxEU.

Dehdari, S. H. (2019). Economic Distress and Support for Radical Right Parties Evidence from Sweden. SSRN Scholarly Paper ID 3160480, Social Science Research Network, Rochester, NY.

Dustmann, C., Vasiljeva, K., and Piil Damm, A. (2019). Refugee Migration and Electoral Outcomes. The Review of Economic Studies, 86(5):2035-2091. Publisher: Oxford Academic.

Fetzer, T. (2019). Did Austerity Cause Brexit? American Economic Review, 109(11):3849-3886.

Fetzer, T., Hensel, L., Hermle, J., and Roth, C. (2020). Coronavirus Perceptions and Economic Anxiety. The Review of Economics and Statistics, pages 1-36. Publisher: MIT Press.

Gamalerio, M., Luca, M., Romarri, A., and Viskanic, M. (2020). Is this the real life or just fantasy? Refugee reception, extreme-right voting, and broadband internet. SSRN Scholarly Paper ID 3277550, Social Science Research Network, Rochester, NY. 
Gidron, N. and Mijs, J. J. B. (2019). Do Changes in Material Circumstances Drive Support for Populist Radical Parties? Panel Data Evidence from the Netherlands during the Great Recession. European Sociological Review, 35(5):637-650. Publisher: Oxford Academic.

Guiso, L., Herrera, H., Morelli, M., and Sonno, T. (2017). Populism: Demand and Supply. SSRN Scholarly Paper ID 2924731, Social Science Research Network, Rochester, NY.

Guriev, S. and Papaioannou, E. (2020). The Political Economy of Populism. SSRN Scholarly Paper ID 3547366, Social Science Research Network, Rochester, NY.

Halla, M., Wagner, A. F., and Zweimüller, J. (2017). Immigration and Voting for the Far Right. Journal of the European Economic Association, 15(6):1341-1385.

Harmon, N. A. (2018). Immigration, Ethnic Diversity, and Political Outcomes: Evidence from Denmark. The Scandinavian Journal of Economics, 120(4):1043-1074. _eprint: https://onlinelibrary.wiley.com/doi/pdf/10.1111/sjoe.12239.

Hatton, T. J. (2016). Immigration, public opinion and the recession in Europe. Economic Policy, 31(86):205-246.

Kuntz, A., Davidov, E., and Semyonov, M. (2017). The dynamic relations between economic conditions and anti-immigrant sentiment: A natural experiment in times of the European economic crisis. International Journal of Comparative Sociology, 58(5):392-415. Publisher: SAGE Publications Ltd.

List, J. A., Shaikh, A. M., and Xu, Y. (2019). Multiple hypothesis testing in experimental economics. Experimental Economics, 22(4):773-793.

Martinangeli, A. and Windsteiger, L. (2019). Immigration vs. Poverty: Causal Impact on Demand for Redistribution in a Survey Experiment. SSRN Scholarly Paper ID 3434292, Social Science Research Network, Rochester, NY.

McGinnity, F. and Kingston, G. (2017). An Irish Welcome? Changing Irish Attitudes to Immigrants and Immigration: The Role of Recession and Immigration. The Economic and Social Review, 48(3, Autumn):253-279. Number: 3, Autumn. 
Mudde, C. (2007). Populist Radical Right Parties in Europe. Cambridge University Press, Cambridge.

Mutz, D. C. (2018). Status threat, not economic hardship, explains the 2016 presidential vote. Proceedings of the National Academy of Sciences, 115(19):E4330-E4339. ISBN: 9781718155114 Publisher: National Academy of Sciences Section: PNAS Plus.

Norris, P. and Inglehart, R. (2019). Cultural Backlash: Trump, Brexit, and Authoritarian Populism. Cambridge University Press, Cambridge.

Otto, A. H. and Steinhardt, M. F. (2014). Immigration and election outcomes - Evidence from city districts in Hamburg. Regional Science and Urban Economics, 45:67-79.

Polavieja, J. G. (2016). Labour-market competition, recession and anti-immigrant sentiments in Europe: occupational and environmental drivers of competitive threat. Socio-Economic Review, 14(3):395-417. Publisher: Oxford Academic.

Romarri, A. (2019). Do Far-Right Mayors Increase the Probability of Hate Crimes? Evidence From Italy. SSRN Electronic Journal.

Steinmayr, A. (2020). Contact versus Exposure: Refugee Presence and Voting for the Far-Right. The Review of Economics and Statistics, pages 1-47. Publisher: MIT Press.

Turner, T. and Cross, C. (2015). Do Attitudes to Immigrants Change in Hard Times? Ireland in a European Context. European Societies, 17(3):372-395. Publisher: Routledge _eprint: https://doi.org/10.1080/14616696.2015.1035298.

Vertier, P., Viskanic, M., and Gamalerio, M. (2019). Dismantling the 'Jungle': Migrant Relocation and Extreme Voting in France. SSRN Scholarly Paper ID 2963641, Social Science Research Network, Rochester, NY.

Vogt Isaksen, J. (2019). The impact of the financial crisis on European attitudes toward immigration. Comparative Migration Studies, 7(1):24.

\section{Appendix}

\section{A Questionnaire}




\section{Public Budget, Social Trust and Socio-Economic Crises}

\section{Investigators:}

- Gianmarco Daniele, Università Bocconi, Università di Milano;

- Andrea Martinangeli, Max Planck Institute for Tax Law and Public Finance;

- Francesco Passarelli, Università Bocconi, Università di Torino;

- Willem Sas, University of Stirling, KU Leuven;

- Lisa Windsteiger, Max Planck Institute for Tax Law and Public Finance;

Survey location: Italy

Target sample: random sample of the adult population representative over age, gender and income (6000 respondents) 


\section{Survey questionnaire draft}

We are non-partisan researchers from an independent research institute.

We would like to know your personal views on matters of public interest.

It is very important that you provide your true opinion, and that you read all the questions very carefully before answering. If you do not know the answer to some question, please provide us with a careful guess. However, please be sure to spend enough time reading and understanding the question. Responding without adequate effort or skipping many questions may result in your responses being flagged for low quality and you may not receive your payment.

It is very important that you complete the entire survey, once you've started. It should take approximately 20 minutes to complete.

Note: Your participation in this study is purely voluntary. No identifying information will be recorded by the researchers. Results may include summary data, but you will never be identified. The data will be stored on our servers and will be kept confidential. The anonymous data collected may be made available to other researchers for replication purposes.

1. Yes, I would like to participate in this survey. / No, I would not like to participate in this survey.

2. What is your gender? (M/F)

3. Please indicate your age:

4. What is your area of residence? [Country dependent] North, NorthE, NorthW, Centre, South, Islands

5. What is your marital status?

a. Single (Never Married/Widowed/Separated/Divorced)

b. Married/Civil partnership/Cohabiting

6. Please indicate how many people live in your household (including yourself): Adults... Children...

7. What is the combined monthly income of your household, after taxes?

[Please include all your household income sources: salaries, scholarships, pension and Social Security benefits, dividends from shares, income from rental properties, child support and alimony etc. We are not interested in the type of income source, only in the total monthly income earned by all the members of your household together.]
1. $<2000$
2. $2000-4000$
3. $4000-6000$
4. $6000-8000$
5. $8000-10000$
6. $>10000$

8. This question's only purpose is that of allowing us to check the quality of the answers we received so far. To continue with the questionnaire, please enter 30 to proceed with the questionnaire.

Information condition display (see Information conditions attachments. A respondent receives only one of the treatments.)

Manipulation check: Please re-enter the information you have seen on the previous page. 


\section{++++ OUTCOME VARIABLE QUESTIONS}

\section{$\underline{\text { VOTING }}$}

10. Imagine the national elections were coming up next [Sunday]. Which party would you vote for? [insert parties per country - this version: Italy]
a. Lega
b. Partito democratico
c. M5S
d. Forza Italia
e. Fratelli d'italia
f. Italia viva
g. Altro. Specificare:
h. Non voterei

\section{$\underline{\text { TRUST }}$}

11. On a scale from 1 to 10 , do you think one can never be careful enough in dealing with people (1), or would you say that most people can be trusted (10)?

\section{NATIONAL SUPPORT}

12. On a scale from 0 to 10 , how much do you trust each of the following: ( $1=$ not at all; $10=$ complete trust)
a. Your national politicians
b. Your national government
c. The police
d. Your public broadcaster
e. Your national scientists/experts

\section{$\underline{\text { ATTACHMENT }}$}

13. People may feel different degrees of attachment to their town or village, to their country or to Europe. On a scale from 1 to 10 , how attached do you feel to
a. [Country] ( $1=$ not at all, $10=$ a lot)
b. Your town/village $(1=$ not at all, $10=$ a lot $)$
c. Europe $(1=$ not at all, $10=$ a lot $)$

\section{EU SUPPORT}

14. On a scale from 1 to 10 , how much do you trust the European Union ( $1=$ not at all, $10=$ a lot).

15. On a scale from 1 to 10 , would you say that [Country] has benefited from being a member of the European Union? $(1=$ not at all, $10=$ a lot $)$

16. If there was a referendum next Sunday with the following question: "Should [Country] remain a member of the European Union or leave the European Union", how would you vote?
a. Remain in the European Union
b. Leave the European Union 
c. I don't know

17. On a scale from 1 to 10 , do you think the $\mathrm{EU}$ is better placed to solve problems than national or regional governments are? ( $1=$ not at all; $10=$ best placed)

\section{IMMIGRATION}

18. On a scale from 1 to 10 , do you think current immigration in your country is too low (1) or too high (10)?

19. On a scale from 1 to 10 , how much do you think the public healthcare system in your country should prioritise [nationality] over immigrants (1= not at all, $10=$ a lot)

\section{GOVERNMENT}

20. People have different views on what the responsibilities of the government should or should not be. On a scale from 1 to 10, do you think the government should
a. levy taxes to subsidise the poor ( $1=$ not at all; $10=$ a lot $)$
b. regulate markets ( $1=$ not at all; $10=$ a lot $)$
c. levy taxes to ensure adequate unemployment insurance ( $1=$ not at all; $10=$ a lot)
d. levy taxes to ensure adequate health care ( $1=$ not at all; $10=$ a lot $)$
e. levy taxes to ensure a reasonable standard of living for the old ( $1=$ not at all; $10=$ a lot)

21. On a scale from 1 to 10 , would you say that
a. the overall fiscal burden in your country is too low (1) or too high (10)?
b. your fiscal burden is too low (1) or too high (10)

\section{LIBERALISM vS POPULISM}

22. On a scale from 1 to 10 , do you agree with the following statements? ( $1=$ fully disagree; $10=$ fully agree)
a. Privacy rights should always be upheld/protected, even if they hinder efforts to combat crime.
b. The people, and not politicians, should make our most important policy decisions.
c. Politicians should have no influence over the content of public broadcasters.
d. Having a strong leader is good for [Country] even if this leader breaks the rules to obtain results.
e. A handful of powerful individuals influences political decisions even in democracies.

23. How much of your personal freedom would you be willing to give up to
a. protect your own safety? (1= none; $10=$ a lot $)$
b. protect the safety of your family? (1=none; $10=$ a lot $)$
c. protect public safety? (1= none; $10=$ a lot $)$

\section{UNIVERSAL VS COMMUNAL}

24. On a scale from 1 to 10 , do you agree that
a. everyone should be treated equally as global citizens, with fundamental rights ( $1=$ not at all; $10=$ fully agree)
b. everyone should be loyal to the community they are part of, and respect its traditions ( $1=$ not at all; $10=$ fully agree)

\section{GLOBALISATION}

25. People have different views about market globalization. On a scale from 1 to 10 , do you favour completely globalised markets (1), complete national self-sufficiency (10). 
TEXT QUESTION HERE (see end of document for details; randomly placed here or at the beginning of outcome questions block)

\section{EU SUPPORT: COVID}

26. On a scale from 1 to 10 , do you think the European Union is managing the COVID-19 epidemic well? ( $1=$ not at all, $10=$ absolutely)

27. On a scale from 1 to 10 , do you think your national government is managing the COVID-19 epidemic well? (1= not at all, 10= absolutely)

28. Which of the following should mostly fund the economic consequences of the COVID-19 crisis?
a. Your national government
b. The European Union
c. Your regional government

29. On a scale from 1 to 10 , do you think there should be solidarity between EU member states to fund the COVID-19 costs? ( $1=$ there should not be; $10=$ there should be)

30. On a scale from 1 to 10 , to what extent do the following statements describe your behavior during the COVID-19 confinement period? ( $1=$ not at all; $10=$ a lot)
a. I worked from home
b. I kept more distance with people than usual
c. I stocked up on food
d. I bought face masks
e. I cleaned my house/apartment with disinfectant products
f. I tried to get or got tested for COVID-19
g. I have donated or volunteered to help combat COVID-19

31. Do you have relatives who are risk patients of COVID-19?
a. Yes
b. No
c. Don't know

32. Please indicate whether the following applies to you:
a. I contracted the virus (YES/NO/DON'T KNOW)
b. Someone in my family or close to me has contracted the virus (YES/NO/DON'T KNOW)
c. At least one of my friends/acquaintances has contracted the virus (YES/NO/DON'T KNOW)

33. On a scale from 1 to 10 , do the following statements about the COVID-19 confinement apply to you personally? ( $1=$ not at all; $10=$ a lot $)$
a. Living together with my family/household was difficult
b. I was concerned about my health
c. Not seeing my friends or family was difficult
d. I thought the social isolation rules were too strict

34. On a scale from 1 to 10 , and when you think about the COVID-19 crisis, how much of your time did you feel:
a. Relaxed (1= never, $10=$ always $)$
b. Angry (1= never, $10=$ always $)$
c. Nervous (1= never, 10= always)
d. Active (1= never, $10=$ always $)$ 
35. On a scale from 1 to 10 , and when you think about COVID-19 crisis, do you think that

a. there were problems with food supplies in [Country] (1= not at all; $10=$ a lot)

b. There will be negative financial consequences for yourself and your family in the future $(1=$ not at all; $10=$ a lot)

c. There will be negative financial consequences for the town in which you live in the future $(1=$ not at all; $10=$ a lot)

36. Is the COVID-19 crisis affecting your job?
a. Yes, mostly positively
b. Yes, mostly negatively
c. Not significantly
d. I don't have a job

37. Is the COVID-19 crisis affecting the job of people close to you?
a. Yes, mostly positively
b. Yes, mostly negatively
c. Not significantly

38. If you would lose your job because of the crisis, how quickly do you think you would find a new job once the economy picks up?
a. In a few weeks
b. In a few months
c. After a year

\section{$\underline{\text { OTHER }}$}

39. Which media do you most frequently get information on world happenings from?

(If you don't find your preferred outlet, please indicate the one that most closely represents it)
a. TV News
b. Social media (social networks, blogs)
c. Radio/podcasts
d. Online newspaper/newspaper app
e. Print newspaper
f. I don't follow the news

40. What is the highest level of education you have completed?
a. Primary school
b. Junior high school (middle school)
c. Professional education
d. Higher education (science/humanities)
e. University degree
f. Doctoral degree

41. What is your current employment status?
a. Employed full-time
b. Employed part-time
c. Self-employed/small business owner
d. Unemployed and looking for a job
e. Not working and not looking for a job/Long-term sick or disabled 
f. Full-time parent, homemaker

g. Retired

h. Student/Pupil

42. Were you born in [Country]?

43. Were both of your parents born in [Country]??

44. What is your province of residence?

45. Where do you see yourself on the political spectrum, where 1 represents the left and 10 represents the right?

46. Did you vote in the last election?

\section{TEXT QUESTION:}

For educational purposes, we are considering to inform students about the importance of the European Union using real texts.

We selected a speech given in front of the European Parliament, which promotes European integration.

It would help us if you could take 5 minutes of your time to read this speech and give us your opinion. Please notice that whether you agree to read the text or not will not affect your payment.

Yes, I want to read the text.

No, I don't want to read the text.

Next page: Thank you very much for your help, you will get to read the speech and give your opinion at the end of this survey.

\section{At the end of the survey (if they clicked yes):}

Thank you for agreeing to review the speech on EU integration which we plan to use for educational purposes. You can find the speech below. You will be able to provide us with your opinion on the next page.

Speech is displayed.

Question after speech:

On a scale from 1 to 10, do you think this text, a speech held by Emmanuel Macron in 2018, can be used to inform students of the advantages and importance of the European Union? (1= No, 10=Yes)

\section{Debriefing}

At the end of the survey we debrief the respondents to avoid them remaining with partial information about the consequences of the epidemic. 


\section{B Information conditions}

This section presents stills of the video frames presented to the respondents as part of the experimental design adopted (translated to English) and links to the videos (in Italian).

Optimist economic Link: https://youtu.be/iOc8m4zcHjI

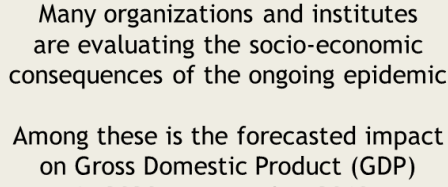

According to an OECD report, the epidemic

will cause Italian GDP

to fall by $0.2 \%$

in 2020 rispetto al 2019.
As a comparison, the financial crisis caused Italian GDP

to fall by $5.7 \%$

in 2009 with respect to 2008 . 
Realistic economic Link: https://youtu.be/-jT9eKtdOec

Many organizations and institutes

are evaluating the socio-economic consequences of the ongoing epidemic

Among these is the forecasted impact on Gross Domestic Product (GDP) in 2020 compared to 2019.

According to Goldman Sachs, the epidemic

will cause Italian GDP

to drop by $11.2 \%$

in 2020 with respect to 2019 .
As a comparison,

the financial crisis

caused Italian GDP

to drop by $5.7 \%$

in 2009 with respect to 2008 .

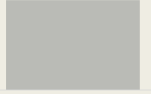


Optimist health https://youtu.be/afVzOzb8egM

The Ministry of Health

computes the number of deaths expected

in a certain period of the year based on the actual number of deaths observed in the same period

in the previous five years.

The number of expected deaths

is computed for each

of the major Italian cities.

This year, the real number of deaths

observed in some Italian cities since the beginning of the epidemic

is only slightly higher $(+5 \%)$

and even

substantially identical $(+2 \%)$

to the expected number.
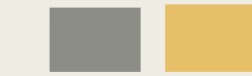

- Numero atteso di decessi t Numero di decessi osservet
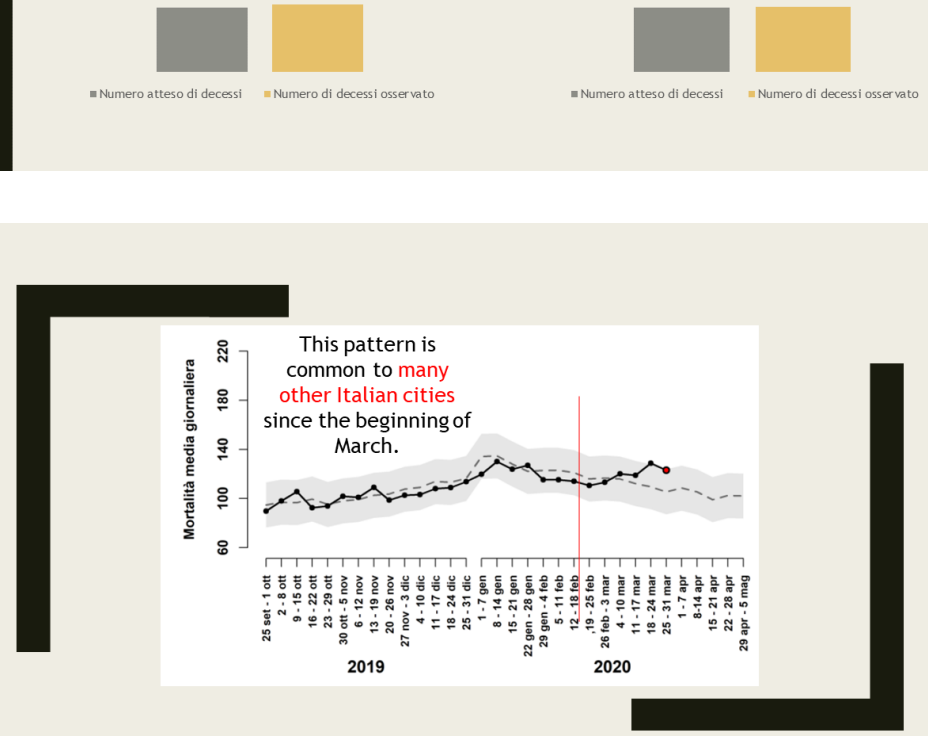
Pessimist health https://youtu.be/MDUs_5poqE0

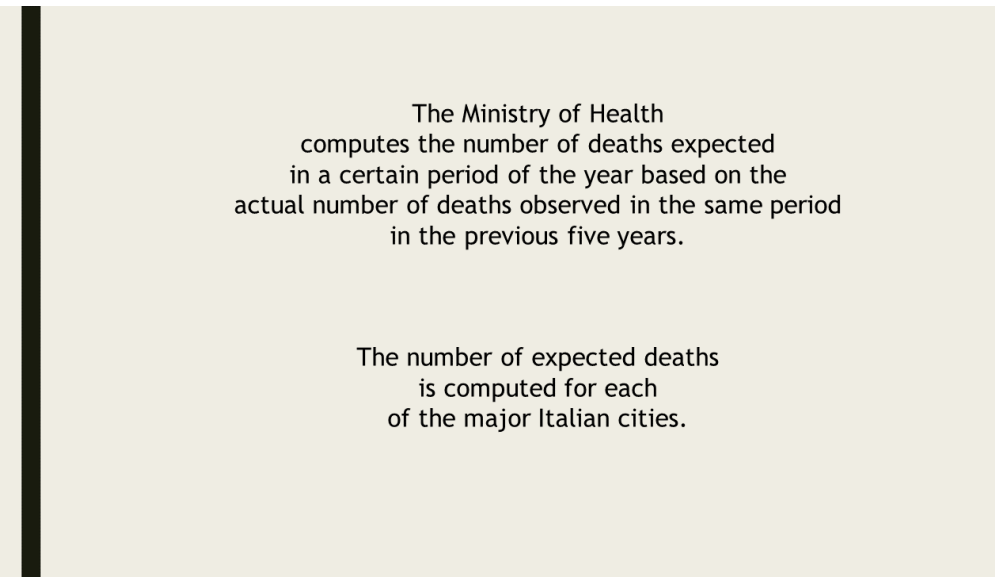

This year, the real number of deaths

observed in some Italian cities since the beginning of the epidemic

is more than double $(+126 \%)$ and even

almost triple $(+195 \%)$

than the expected number.
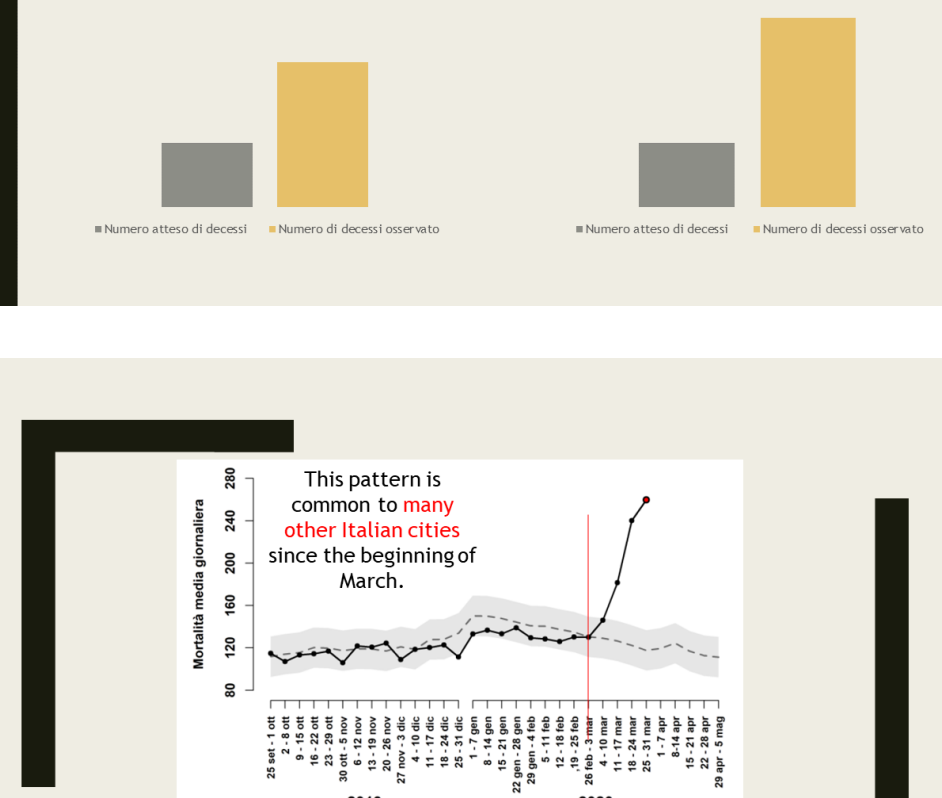

\section{品 This pattern is}

产

since the beginning of

March.

蛋

$\frac{\infty}{2}$

$\sqrt{2}$

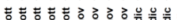

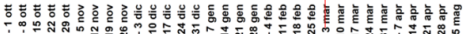

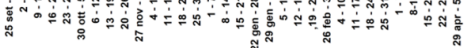

2019

2020 


\section{Tables}

\section{C.1 Sample balance}

Table C1 reports sample balance checks by information condition and economic and health dimensions over individual, regional and provincial observables.

\begin{tabular}{|c|c|c|c|c|c|c|}
\hline & (1) & $(2)$ & (3) & $(4)$ & (5) & (6) \\
\hline & \multicolumn{3}{|c|}{ Economic dimension } & \multicolumn{3}{|c|}{ Health dimension } \\
\hline & $\begin{array}{l}\text { Optimist } \\
\text { mean }\end{array}$ & $\begin{array}{l}\text { Pessimist } \\
\text { mean }\end{array}$ & $\Delta$ & $\begin{array}{l}\text { Optimist } \\
\text { mean }\end{array}$ & $\begin{array}{l}\text { Pessimist } \\
\text { mean }\end{array}$ & $\Delta$ \\
\hline \multirow[t]{2}{*}{ Unemployed } & 0.079 & 0.090 & 0.011 & 0.086 & 0.105 & $0.018^{*}$ \\
\hline & $(0.269)$ & $(0.286)$ & $(0.282)$ & $(0.281)$ & $(0.306)$ & $(0.089)$ \\
\hline \multirow[t]{2}{*}{ College } & 0.386 & 0.406 & 0.021 & 0.397 & 0.432 & $0.035^{*}$ \\
\hline & $(0.487)$ & $(0.491)$ & $(0.250)$ & $(0.490)$ & $(0.496)$ & $(0.054)$ \\
\hline \multirow[t]{2}{*}{ Italian born } & 0.966 & 0.966 & 0.000 & 0.962 & 0.962 & -0.000 \\
\hline & $(0.182)$ & $(0.180)$ & $(0.948)$ & $(0.191)$ & $(0.191)$ & $(0.994)$ \\
\hline \multirow[t]{2}{*}{ Female } & 0.495 & 0.515 & 0.020 & 0.496 & 0.504 & 0.008 \\
\hline & $(0.500)$ & $(0.500)$ & $(0.271)$ & $(0.500)$ & $(0.500)$ & $(0.660)$ \\
\hline \multirow[t]{2}{*}{ Age } & 1.953 & 1.962 & 0.009 & 1.978 & 1.895 & $-0.082^{*}$ \\
\hline & $(1.356)$ & $(1.342)$ & $(0.857)$ & $(1.371)$ & $(1.343)$ & $(0.099)$ \\
\hline \multirow[t]{2}{*}{ Family size } & 3.121 & 3.104 & -0.017 & 3.078 & 3.107 & 0.028 \\
\hline & $(1.210)$ & $(1.218)$ & $(0.702)$ & $(1.203)$ & $(1.186)$ & $(0.517)$ \\
\hline \multirow[t]{2}{*}{ Income classif. } & 0.900 & 0.900 & -0.001 & 0.919 & 0.863 & $-0.055^{*}$ \\
\hline & $(0.804)$ & $(0.798)$ & $(0.982)$ & $(0.814)$ & $(0.795)$ & $(0.061)$ \\
\hline \multirow[t]{2}{*}{ Single } & 0.378 & 0.373 & -0.005 & 0.365 & 0.371 & 0.006 \\
\hline & $(0.485)$ & $(0.484)$ & $(0.764)$ & $(0.482)$ & $(0.483)$ & $(0.740)$ \\
\hline \multirow[t]{2}{*}{ Reg. population (times100k) } & 49.982 & 51.022 & 1.040 & 50.708 & 49.837 & -0.871 \\
\hline & $(26.651)$ & $(26.795)$ & $(0.286)$ & $(26.727)$ & $(26.327)$ & $(0.371)$ \\
\hline \multirow[t]{2}{*}{ GDP p.c. } & 38.191 & 38.651 & 0.460 & 38.382 & 38.160 & -0.222 \\
\hline & $(10.515)$ & $(10.429)$ & $(0.229)$ & $(10.477)$ & $(10.445)$ & $(0.563)$ \\
\hline \multirow[t]{2}{*}{ Unempl. rate (15-64) } & 11.505 & 11.452 & -0.053 & 11.532 & 11.645 & 0.113 \\
\hline & $(5.863)$ & $(5.786)$ & $(0.804)$ & $(5.881)$ & $(5.900)$ & $(0.600)$ \\
\hline \multirow[t]{2}{*}{ Life exp. } & 82.682 & 82.672 & -0.010 & 82.665 & 82.650 & -0.015 \\
\hline & $(0.727)$ & $(0.719)$ & $(0.704)$ & $(0.744)$ & $(0.747)$ & $(0.582)$ \\
\hline \multirow[t]{2}{*}{ Cum. daily new cases p.c. } & 0.004 & 0.004 & -0.000 & 0.004 & 0.004 & -0.000 \\
\hline & $(0.003)$ & $(0.003)$ & $(0.951)$ & $(0.003)$ & $(0.003)$ & $(0.506)$ \\
\hline \multirow[t]{2}{*}{ Immigrant pop. (prov. \%) } & 0.351 & 0.467 & $0.116^{* * *}$ & 0.403 & 0.419 & 0.016 \\
\hline & $(0.874)$ & $(1.043)$ & $(0.001)$ & $(0.949)$ & $(0.972)$ & $(0.656)$ \\
\hline Observations & 1,524 & 1,484 & 3,008 & 1,485 & 1,483 & 2,968 \\
\hline
\end{tabular}

Table C1: Sample balance table by optimist or pessimist information within the economic and health dimensions. 


\section{C.2 Probit regressions for voting intentions}

Tables $\mathrm{C} 2$ and $\mathrm{C} 3$ report probit estimations corresponding to the linear probability models reported in Tables 5 and 6. All the findings reported in Section 2.1 remain here confirmed.

Table C2: Probit regression of voting intentions: economic dimension

\begin{tabular}{|c|c|c|c|}
\hline \multirow[b]{2}{*}{ VARIABLES } & \multicolumn{3}{|c|}{ Economic dimension } \\
\hline & Anti-immigration & Populism & Incumbent \\
\hline \multirow[t]{2}{*}{ Pessimistic info. } & $0.093^{*}$ & $0.077^{*}$ & -0.023 \\
\hline & $(0.052)$ & $(0.042)$ & $(0.043)$ \\
\hline \multirow[t]{2}{*}{ Unemployed } & -0.021 & 0.007 & -0.020 \\
\hline & $(0.094)$ & $(0.077)$ & $(0.095)$ \\
\hline \multirow[t]{2}{*}{ College } & $-0.095^{* *}$ & $-0.229 * * *$ & 0.043 \\
\hline & $(0.044)$ & $(0.042)$ & $(0.046)$ \\
\hline \multirow[t]{2}{*}{ Female } & 0.041 & -0.064 & $-0.086^{*}$ \\
\hline & $(0.057)$ & $(0.050)$ & $(0.048)$ \\
\hline \multirow[t]{2}{*}{ Income tertile $=2$} & 0.038 & -0.003 & 0.103 \\
\hline & $(0.079)$ & $(0.067)$ & $(0.063)$ \\
\hline \multirow[t]{2}{*}{ Income tertile $=3$} & 0.013 & -0.077 & $0.224^{* * *}$ \\
\hline & $(0.057)$ & $(0.066)$ & $(0.054)$ \\
\hline \multirow[t]{2}{*}{ GDP p.c. } & $0.021^{* *}$ & 0.015 & -0.013 \\
\hline & $(0.010)$ & $(0.009)$ & $(0.012)$ \\
\hline \multirow[t]{2}{*}{ Unemployment (\% 15-64) } & $0.030^{*}$ & $0.037^{* *}$ & -0.015 \\
\hline & $(0.016)$ & $(0.015)$ & $(0.018)$ \\
\hline \multirow[t]{2}{*}{ C19 } & -17.752 & -23.607 & -1.602 \\
\hline & $(18.474)$ & $(18.688)$ & $(21.245)$ \\
\hline \multirow[t]{2}{*}{ Immigrant pop. ( $\%$ prov.) } & -0.027 & 0.012 & 0.057 \\
\hline & $(0.032)$ & $(0.034)$ & $(0.042)$ \\
\hline \multirow[t]{2}{*}{ Constant } & $-27.723^{* * *}$ & $-10.823^{*}$ & $16.476^{* *}$ \\
\hline & $(6.927)$ & $(5.587)$ & $(6.641)$ \\
\hline \multicolumn{4}{|l|}{ Omitted controls: } \\
\hline - Individual & $\checkmark$ & $\checkmark$ & $\checkmark$ \\
\hline - Regional & $\checkmark$ & $\checkmark$ & $\checkmark$ \\
\hline - Provincial & $\checkmark$ & $\checkmark$ & $\checkmark$ \\
\hline Observations & 3,003 & 3,003 & 3,003 \\
\hline
\end{tabular}

The table displays the results form Probit regressions of voting intentions on our pessimistic economic information intervention. Omitted individual controls: age, family size, italian born, single. Omitted regional controls: life expectancy. Omitted provincial controls: population.

Robust standard errors, clustered at province level, in parentheses.

*** $\mathrm{p}<0.01,{ }^{* *} \mathrm{p}<0.05,{ }^{*} \mathrm{p}<0.1$ 
Table C3: Probit regression of voting intentions: health dimension

\begin{tabular}{|c|c|c|c|}
\hline \multirow[b]{2}{*}{ VARIABLES } & \multicolumn{3}{|c|}{ Health dimension } \\
\hline & Anti-immigration & Populism & Incumbent \\
\hline \multirow[t]{2}{*}{ Pessimistic info. $=1$} & 0.004 & -0.035 & -0.061 \\
\hline & $(0.052)$ & $(0.045)$ & $(0.038)$ \\
\hline \multirow[t]{2}{*}{ Unemployed } & 0.007 & -0.033 & $-0.204^{* * *}$ \\
\hline & $(0.086)$ & $(0.077)$ & $(0.073)$ \\
\hline \multirow[t]{2}{*}{ College } & $-0.213^{* * *}$ & $-0.218^{* * *}$ & $0.177^{* * *}$ \\
\hline & $(0.058)$ & $(0.054)$ & $(0.068)$ \\
\hline \multirow[t]{2}{*}{ Female } & -0.037 & $-0.111^{* *}$ & $-0.124^{* *}$ \\
\hline & $(0.051)$ & $(0.048)$ & $(0.050)$ \\
\hline \multirow[t]{2}{*}{ Income tertile $=2$} & 0.050 & 0.025 & 0.099 \\
\hline & $(0.058)$ & $(0.063)$ & $(0.070)$ \\
\hline \multirow[t]{2}{*}{ Income tertile $=3$} & 0.002 & -0.064 & $0.181^{* *}$ \\
\hline & $(0.068)$ & $(0.068)$ & $(0.079)$ \\
\hline \multirow[t]{2}{*}{ GDP p.c. } & $0.024^{* *}$ & 0.013 & $-0.020 * *$ \\
\hline & $(0.011)$ & $(0.010)$ & $(0.010)$ \\
\hline \multirow[t]{2}{*}{ Unemployment (\% 15-64) } & 0.024 & $0.043^{* *}$ & -0.006 \\
\hline & $(0.023)$ & $(0.018)$ & $(0.021)$ \\
\hline \multirow[t]{2}{*}{ C19 } & 2.132 & 11.572 & 14.817 \\
\hline & $(18.253)$ & $(18.353)$ & $(17.756)$ \\
\hline \multirow[t]{2}{*}{ Immigrant pop. ( $\%$ prov.) } & -0.031 & $-0.058^{*}$ & 0.009 \\
\hline & $(0.037)$ & $(0.035)$ & $(0.033)$ \\
\hline \multirow[t]{2}{*}{ Constant } & -9.537 & -2.477 & 8.457 \\
\hline & $(9.046)$ & $(6.560)$ & $(8.300)$ \\
\hline \multicolumn{4}{|l|}{ Omitted controls: } \\
\hline - Individual & $\checkmark$ & $\checkmark$ & $\checkmark$ \\
\hline - Regional & $\checkmark$ & $\checkmark$ & $\checkmark$ \\
\hline - Provincial & $\checkmark$ & $\checkmark$ & $\checkmark$ \\
\hline Observations & 2,956 & 2,956 & 2,956 \\
\hline
\end{tabular}

The table displays the results form Probit regressions of voting intentions on our pessimistic health information intervention. Omitted individual controls: age, family size, italian born, single. Omitted regional controls: life expectancy. Omitted provincial controls: population.

Robust standard errors, clustered at province level, in parentheses.

$* * * \mathrm{p}<0.01,{ }^{* *} \mathrm{p}<0.05,{ }^{*} \mathrm{p}<0.1$

\section{C.3 Further analyses}

Tables C4 and C5 report analyses of further outcome variables we included in our survey: a measure of the respondents' perceived own tax burden, their demand for tax-financed welfare state interventions in the areas of poverty relief, public healthcare service provision, unemployment income replacement and pension system. Neither of our economic nor health pessimistic information has any impact on these outcomes. 
Table C4: OLS regression of perceived own tax burden and demand for tax-financed welfare state interventions: economic dimension

\begin{tabular}{|c|c|c|c|c|c|}
\hline \multirow{3}{*}{ VARIABLES } & \multicolumn{5}{|c|}{ Economic dimension } \\
\hline & \multirow[t]{2}{*}{ Own tax burden } & \multicolumn{4}{|c|}{ Demand for tax-financed } \\
\hline & & Poverty rel. & Public health & Unempl. inc. & Pensions \\
\hline \multirow[t]{2}{*}{ Pessimistic info. } & 0.014 & -0.025 & 0.009 & -0.025 & 0.011 \\
\hline & $(0.029)$ & $(0.032)$ & $(0.031)$ & $(0.031)$ & $(0.034)$ \\
\hline \multirow[t]{2}{*}{ Unemployed } & 0.011 & -0.030 & -0.081 & -0.016 & 0.023 \\
\hline & $(0.063)$ & $(0.076)$ & $(0.088)$ & $(0.087)$ & $(0.073)$ \\
\hline \multirow[t]{2}{*}{ College } & $-0.093^{* *}$ & $0.106^{* * *}$ & $0.110^{* * *}$ & 0.049 & $0.093^{* *}$ \\
\hline & $(0.036)$ & $(0.039)$ & $(0.041)$ & $(0.039)$ & $(0.039)$ \\
\hline \multirow[t]{2}{*}{ Female } & 0.054 & $-0.115^{* * *}$ & $-0.148^{* * *}$ & $-0.129 * * *$ & $-0.091^{* * *}$ \\
\hline & $(0.040)$ & $(0.034)$ & $(0.037)$ & $(0.034)$ & $(0.033)$ \\
\hline \multirow[t]{2}{*}{ Income tertile $=2$} & -0.061 & 0.039 & $0.152^{* * *}$ & 0.024 & 0.028 \\
\hline & $(0.041)$ & $(0.050)$ & $(0.046)$ & $(0.047)$ & $(0.045)$ \\
\hline \multirow[t]{2}{*}{ Income tertile $=3$} & -0.038 & $0.140 * * *$ & $0.257^{* * *}$ & $0.138^{* * *}$ & $0.120^{* * *}$ \\
\hline & $(0.048)$ & $(0.042)$ & $(0.043)$ & $(0.040)$ & $(0.041)$ \\
\hline \multirow[t]{2}{*}{ GDP p.c. } & 0.003 & -0.011 & $-0.010^{*}$ & $-0.016^{* *}$ & -0.007 \\
\hline & $(0.007)$ & $(0.007)$ & $(0.006)$ & $(0.007)$ & $(0.007)$ \\
\hline \multirow[t]{2}{*}{ Unemployment (\% 15-64) } & $0.021^{*}$ & -0.008 & -0.013 & -0.003 & 0.000 \\
\hline & $(0.011)$ & $(0.012)$ & $(0.011)$ & $(0.011)$ & $(0.011)$ \\
\hline \multirow[t]{2}{*}{ C19 } & 4.405 & 3.309 & 2.197 & 17.919 & 2.709 \\
\hline & $(13.164)$ & $(13.552)$ & $(10.874)$ & $(12.509)$ & $(12.227)$ \\
\hline \multirow[t]{2}{*}{ Immigrant pop. ( $\%$ prov.) } & $0.043^{*}$ & 0.035 & 0.021 & $0.059 * * *$ & 0.031 \\
\hline & $(0.023)$ & $(0.025)$ & $(0.020)$ & $(0.023)$ & $(0.023)$ \\
\hline \multirow[t]{2}{*}{ Constant } & -3.901 & 1.420 & 0.665 & -2.602 & -1.147 \\
\hline & $(4.340)$ & $(5.331)$ & $(4.333)$ & $(5.006)$ & $(4.765)$ \\
\hline \multicolumn{6}{|l|}{ Omitted controls: } \\
\hline - Individual & r & $\checkmark$ & $\checkmark$ & $\checkmark$ & $\checkmark$ \\
\hline - Regional & $\checkmark$ & $\checkmark$ & $\checkmark$ & $\checkmark$ & $\checkmark$ \\
\hline - Provincial & $\checkmark$ & $\checkmark$ & $\checkmark$ & $\checkmark$ & $\checkmark$ \\
\hline Observations & 3,003 & 3,003 & 3,003 & 3,003 & 3,003 \\
\hline R-squared & 0.045 & 0.027 & 0.041 & 0.029 & 0.045 \\
\hline
\end{tabular}

The table displays the results form OLS regressions of perceived own tax burden and demand for tax-financed poverty programmes, public healthcare, unemployment income replacement and pensions. Omitted individual controls: age, family size, italian born, single. Omitted regional controls: life expectancy. Omitted provincial controls: population.

Robust standard errors, clustered at province level, in parentheses.

$* * * \mathrm{p}<0.01,{ }^{* *} \mathrm{p}<0.05,{ }^{*} \mathrm{p}<0.1$ 
Table C5: OLS regression of perceived own tax burden and demand for tax-financed welfare state interventions: health dimension

\begin{tabular}{|c|c|c|c|c|c|}
\hline \multirow{3}{*}{ VARIABLES } & \multicolumn{5}{|c|}{ Health dimension } \\
\hline & \multirow[t]{2}{*}{ Own tax burden } & \multicolumn{4}{|c|}{ Demand for tax-financed } \\
\hline & & Poverty rel. & Public health & Unempl. inc. & Pensions \\
\hline \multirow[t]{2}{*}{ Pessimistic info. } & -0.061 & -0.018 & 0.009 & -0.008 & -0.021 \\
\hline & $(0.037)$ & $(0.040)$ & $(0.038)$ & $(0.039)$ & $(0.039)$ \\
\hline \multirow[t]{2}{*}{ Unemployed } & 0.098 & $0.167^{* *}$ & 0.047 & 0.088 & 0.070 \\
\hline & $(0.064)$ & $(0.068)$ & $(0.079)$ & $(0.067)$ & $(0.072)$ \\
\hline \multirow[t]{2}{*}{ College } & $-0.153^{* * *}$ & $0.093^{* *}$ & $0.145^{* * *}$ & $0.078^{*}$ & 0.035 \\
\hline & $(0.033)$ & $(0.039)$ & $(0.043)$ & $(0.041)$ & $(0.037)$ \\
\hline \multirow[t]{2}{*}{ Female } & $0.118^{* * *}$ & $-0.243^{* * *}$ & $-0.253^{* * *}$ & $-0.234^{* * *}$ & $-0.174^{* * *}$ \\
\hline & $(0.034)$ & $(0.036)$ & $(0.037)$ & $(0.041)$ & $(0.040)$ \\
\hline \multirow[t]{2}{*}{ Income tertile $=2$} & -0.041 & 0.057 & $0.117^{* *}$ & 0.039 & 0.061 \\
\hline & $(0.050)$ & $(0.048)$ & $(0.046)$ & $(0.045)$ & $(0.057)$ \\
\hline \multirow{2}{*}{ Income tertile $=3$} & $-0.080^{* *}$ & 0.072 & $0.114^{*}$ & 0.026 & 0.056 \\
\hline & $(0.040)$ & $(0.060)$ & $(0.063)$ & $(0.049)$ & $(0.056)$ \\
\hline \multirow[t]{2}{*}{ GDP p.c. } & -0.004 & 0.009 & $0.013^{*}$ & 0.003 & 0.009 \\
\hline & $(0.008)$ & $(0.007)$ & $(0.007)$ & $(0.008)$ & $(0.007)$ \\
\hline \multirow[t]{2}{*}{ Unemployment (\% 15-64) } & 0.015 & 0.012 & 0.020 & 0.014 & 0.017 \\
\hline & $(0.016)$ & $(0.014)$ & $(0.013)$ & $(0.015)$ & $(0.014)$ \\
\hline \multirow[t]{2}{*}{ C19 } & 15.480 & $-30.288^{* *}$ & -19.183 & -9.308 & -18.017 \\
\hline & $(15.385)$ & $(13.612)$ & $(12.527)$ & $(13.773)$ & $(13.507)$ \\
\hline \multirow[t]{2}{*}{ Immigrant pop. ( $\%$ prov.) } & 0.001 & -0.032 & -0.024 & 0.006 & -0.007 \\
\hline & $(0.027)$ & $(0.023)$ & $(0.023)$ & $(0.025)$ & $(0.023)$ \\
\hline \multirow[t]{2}{*}{ Constant } & -6.201 & -2.565 & -6.356 & -5.171 & -4.030 \\
\hline & $(5.116)$ & $(5.043)$ & $(5.179)$ & $(5.536)$ & $(4.772)$ \\
\hline \multicolumn{6}{|l|}{ Omitted controls: } \\
\hline - Individual & $\checkmark$ & $\checkmark$ & $\checkmark$ & $\checkmark$ & $\checkmark$ \\
\hline - Regional & $\checkmark$ & $\checkmark$ & $\checkmark$ & $\checkmark$ & $\checkmark$ \\
\hline - Provincial & $\checkmark$ & $\checkmark$ & $\checkmark$ & $\checkmark$ & $\checkmark$ \\
\hline Observations & 2,956 & 2,956 & 2,956 & 2,956 & 2,956 \\
\hline R-squared & 0.052 & 0.033 & 0.036 & 0.029 & 0.041 \\
\hline
\end{tabular}

The table displays the results form OLS regressions of perceived own tax burden and demand for tax-financed poverty programmes, public healthcare, unemployment income replacement and pensions. Omitted individual controls: age, family size, italian born, single. Omitted regional controls: life expectancy. Omitted provincial controls: population.

Robust standard errors, clustered at province level, in parentheses.

$* * * \mathrm{p}<0.01,{ }^{*} * \mathrm{p}<0.05,{ }^{*} \mathrm{p}<0.1$ 


\section{Further heterogeneities}

We now investigate further potential heterogeneous impacts of our pessimistic information interventions. We investigate heterogeneous effects with respect to the Covid-19 incidence at regional level, to the respondents' income and their self-reported levels of exposure to the virus.

\section{D.1 Covid severity}

From Table D1 the impact of receiving pessimistic economic information observed in Table 3 appears to be driven by respondents in regions in which the epidemic struck relatively harder (notice that the linear terms $\beta_{1}$ for receiving pessimistic information are statistical zeros for all our outcome variables). ${ }^{17}$

\footnotetext{
${ }^{17}$ The heterogeneous effects here uncovered with respect to Covid-19 incidence are structurally confounded with potential heterogeneous heterogeneous effects with respect to regional GDP. In our sample, regional GDP per capita and cumulated regional Covid-19 cases per capita are extremely highly correlated: The northern and richer Italian regions were much more heavily affected by the epidemic (Spearman rank correlation coefficient $\rho=0.85, p<0.001$ ). Interacting our interventions with regional GDP yields substantially identical results.
} 
Table D1: OLS regression of immigration sentiments: economic dimension

\begin{tabular}{|c|c|c|c|}
\hline \multirow[b]{2}{*}{ VARIABLES } & \multicolumn{3}{|c|}{ Economic dimension } \\
\hline & Too many immigrants & Health exp to natives & General tax burden \\
\hline \multirow[t]{2}{*}{ Pessimistic info. } & 0.067 & 0.020 & -0.001 \\
\hline & $(0.057)$ & $(0.044)$ & $(0.048)$ \\
\hline \multirow[t]{2}{*}{ C19 } & 0.357 & 15.355 & -23.773 \\
\hline & $(13.464)$ & $(12.844)$ & $(14.669)$ \\
\hline \multirow[t]{2}{*}{ Pessimistic info. $\times$ C19 } & 11.307 & $20.143^{* *}$ & $17.304^{*}$ \\
\hline & $(8.978)$ & $(8.039)$ & $(9.631)$ \\
\hline \multirow[t]{2}{*}{ Unemployed } & $0.135^{* *}$ & -0.039 & 0.083 \\
\hline & $(0.067)$ & $(0.067)$ & $(0.066)$ \\
\hline \multirow[t]{2}{*}{ College } & $-0.251^{* * *}$ & $-0.188^{* * *}$ & -0.055 \\
\hline & $(0.037)$ & $(0.034)$ & $(0.037)$ \\
\hline \multirow[t]{2}{*}{ Female } & $0.135^{* * *}$ & $0.077 * *$ & -0.035 \\
\hline & $(0.034)$ & $(0.036)$ & $(0.033)$ \\
\hline \multirow[t]{2}{*}{ Income tertile $=2$} & -0.075 & $-0.105^{* *}$ & 0.025 \\
\hline & $(0.049)$ & $(0.051)$ & $(0.044)$ \\
\hline \multirow[t]{2}{*}{ Income tertile $=3$} & -0.053 & -0.085 & -0.030 \\
\hline & $(0.051)$ & $(0.056)$ & $(0.053)$ \\
\hline \multirow[t]{2}{*}{ GDP p.c. } & 0.003 & 0.001 & $0.013^{*}$ \\
\hline & $(0.007)$ & $(0.007)$ & $(0.007)$ \\
\hline \multirow[t]{2}{*}{ Unemployment (\% 15-64) } & $0.022^{*}$ & $0.025^{* *}$ & $0.031^{* * *}$ \\
\hline & $(0.012)$ & $(0.012)$ & $(0.010)$ \\
\hline \multirow[t]{2}{*}{ Immigrant pop. ( $\%$ prov.) } & 0.015 & 0.025 & -0.025 \\
\hline & $(0.023)$ & $(0.025)$ & $(0.026)$ \\
\hline \multirow[t]{2}{*}{ Constant } & $-11.172^{* *}$ & -9.307 & $-9.750^{* *}$ \\
\hline & $(5.043)$ & $(6.923)$ & $(3.724)$ \\
\hline \multicolumn{4}{|l|}{ Omitted controls: } \\
\hline - Individual & $\checkmark$ & $\checkmark$ & $\checkmark$ \\
\hline - Regional & $\checkmark$ & $\checkmark$ & $\checkmark$ \\
\hline - Provincial & $\checkmark$ & $\checkmark$ & $\checkmark$ \\
\hline Observations & 3,003 & 3,003 & 3,003 \\
\hline R-squared & 0.052 & 0.040 & 0.044 \\
\hline
\end{tabular}

The table displays the results form OLS regressions of our immigration sentiment and tax burden outcomes on our pessimistic economic information intervention interacted with the per capita number of cumulated new Covid-19 cases in the respondents' region. Omitted individual controls: age, family size, italian born, single. Omitted regional controls: life expectancy. Omitted provincial controls: population.

Robust standard errors, clustered at province level, in parentheses.

$* * * \mathrm{p}<0.01,{ }^{* *} \mathrm{p}<0.05,{ }^{*} \mathrm{p}<0.1$ 
Table D2: OLS regression of immigration sentiments: health dimension

\begin{tabular}{|c|c|c|c|}
\hline \multirow[b]{2}{*}{ VARIABLES } & \multicolumn{3}{|c|}{ Health dimension } \\
\hline & Too many immigrants & Health exp to natives & General tax burden \\
\hline \multirow[t]{2}{*}{ Pessimistic info. } & 0.076 & 0.049 & -0.031 \\
\hline & $(0.051)$ & $(0.053)$ & $(0.061)$ \\
\hline \multirow[t]{2}{*}{ C19 } & 4.014 & -10.261 & -4.128 \\
\hline & $(13.611)$ & $(14.333)$ & $(19.400)$ \\
\hline \multirow[t]{2}{*}{ Pessimistic info. $\times$ C19 } & -5.442 & 5.666 & 0.820 \\
\hline & $(13.015)$ & $(12.614)$ & $(14.595)$ \\
\hline \multirow[t]{2}{*}{ Unemployed } & 0.029 & -0.014 & 0.067 \\
\hline & $(0.067)$ & $(0.065)$ & $(0.062)$ \\
\hline \multirow[t]{2}{*}{ College } & $-0.216^{* * *}$ & $-0.148^{* * *}$ & $-0.087^{*}$ \\
\hline & $(0.038)$ & $(0.039)$ & $(0.047)$ \\
\hline \multirow[t]{2}{*}{ Female } & $0.187^{* * *}$ & $0.105^{* * *}$ & -0.027 \\
\hline & $(0.035)$ & $(0.040)$ & $(0.039)$ \\
\hline \multirow[t]{2}{*}{ Income tertile $=2$} & $-0.122^{* * *}$ & $-0.089 * *$ & -0.011 \\
\hline & $(0.042)$ & $(0.043)$ & $(0.049)$ \\
\hline \multirow[t]{2}{*}{ Income tertile $=3$} & $-0.228 * * *$ & $-0.132^{* * *}$ & -0.085 \\
\hline & $(0.042)$ & $(0.044)$ & $(0.057)$ \\
\hline \multirow[t]{2}{*}{ GDP p.c. } & 0.003 & 0.001 & -0.006 \\
\hline & $(0.008)$ & $(0.008)$ & $(0.011)$ \\
\hline \multirow[t]{2}{*}{ Unemployment (\% 15-64) } & 0.013 & 0.011 & -0.011 \\
\hline & $(0.015)$ & $(0.012)$ & $(0.018)$ \\
\hline \multirow[t]{2}{*}{ Immigrant pop. ( $\%$ prov.) } & -0.015 & 0.023 & 0.002 \\
\hline & $(0.025)$ & $(0.026)$ & $(0.033)$ \\
\hline \multirow[t]{2}{*}{ Constant } & -7.636 & $-11.441^{* *}$ & -2.008 \\
\hline & $(5.698)$ & $(4.402)$ & $(5.648)$ \\
\hline \multicolumn{4}{|l|}{ Omitted controls: } \\
\hline - Individual & $\checkmark$ & $\checkmark$ & $\checkmark$ \\
\hline - Regional & $\checkmark$ & $\checkmark$ & $\checkmark$ \\
\hline - Provincial & $\checkmark$ & $\checkmark$ & $\checkmark$ \\
\hline Observations & 2,956 & 2,956 & 2,956 \\
\hline R-squared & 0.060 & 0.059 & 0.038 \\
\hline \multicolumn{4}{|c|}{$\begin{array}{l}\text { Robust standard errors in parentheses } \\
\quad * * * \mathrm{p}<0.01, * * \mathrm{p}<0.05, * \mathrm{p}<0.1\end{array}$} \\
\hline \multicolumn{4}{|c|}{$\begin{array}{l}\text { The table displays the results form OLS regressions of our immigration sentiment and } \\
\text { tax burden outcomes on our pessimistic health information intervention interacted } \\
\text { with the per capita number of cumulated new Covid- } 19 \text { cases in the respondents' } \\
\text { region. Omitted individual controls: age, family size, italian born, single. Omitted } \\
\text { regional controls: life expectancy. Omitted provincial controls: population. } \\
\text { Robust standard errors, clustered at province level, in parentheses. } \\
* * * \mathrm{p}<0.01, * * \mathrm{p}<0.05, * \mathrm{p}<0.1\end{array}$} \\
\hline
\end{tabular}

On the other hand, there seems to be no interaction between our intervention and the regional severity of the epidemic in the health domain. 


\section{D.2 Income heterogeneity}

Tables D3 and D4 display the results from the analysis of the interaction of our information interventions with the respondents' income tertile (sample distribution). Neither of our economic nor health pessimistic information conditions interacts in any significant way with the respondents' income. 
Table D3: OLS regression of immigration sentiments: economic dimension

\begin{tabular}{|c|c|c|c|}
\hline \multirow[b]{2}{*}{ VARIABLES } & \multicolumn{3}{|c|}{$\begin{array}{l}\text { Economic dimension } \\
\end{array}$} \\
\hline & Too many immigrants & Health exp to natives & General tax burden \\
\hline \multirow[t]{2}{*}{ Pessimistic info. } & 0.086 & 0.059 & 0.086 \\
\hline & $(0.053)$ & $(0.060)$ & $(0.052)$ \\
\hline \multirow[t]{2}{*}{ Income tertile $=2$} & $-0.106^{*}$ & $-0.131^{* *}$ & 0.057 \\
\hline & $(0.054)$ & $(0.060)$ & $(0.062)$ \\
\hline \multirow[t]{2}{*}{ Income tertile $=3$} & -0.061 & -0.127 & -0.033 \\
\hline & $(0.071)$ & $(0.078)$ & $(0.079)$ \\
\hline \multirow[t]{2}{*}{ Pessimistic info. $\times$ Income tertile $=2$} & 0.063 & 0.055 & -0.058 \\
\hline & $(0.079)$ & $(0.077)$ & $(0.075)$ \\
\hline \multirow[t]{2}{*}{ Pessimistic info. $\times$ Income tertile $=3$} & 0.015 & 0.082 & 0.008 \\
\hline & $(0.090)$ & $(0.099)$ & $(0.101)$ \\
\hline \multirow[t]{2}{*}{ Unemployed } & $0.136^{* *}$ & -0.037 & 0.089 \\
\hline & $(0.066)$ & $(0.066)$ & $(0.066)$ \\
\hline \multirow[t]{2}{*}{ College } & $-0.250 * * *$ & $-0.188^{* * *}$ & -0.055 \\
\hline & $(0.037)$ & $(0.034)$ & $(0.037)$ \\
\hline \multirow[t]{2}{*}{ Female } & $0.134^{* * *}$ & $0.076^{* *}$ & -0.034 \\
\hline & $(0.034)$ & $(0.035)$ & $(0.034)$ \\
\hline \multirow[t]{2}{*}{ GDP p.c. } & 0.003 & 0.001 & $0.013^{*}$ \\
\hline & $(0.007)$ & $(0.007)$ & $(0.007)$ \\
\hline \multirow[t]{2}{*}{ Unemployment (\% 15-64) } & $0.022^{*}$ & $0.025^{* *}$ & $0.031^{* * *}$ \\
\hline & $(0.012)$ & $(0.012)$ & $(0.010)$ \\
\hline \multirow[t]{2}{*}{ C19 } & 5.473 & $25.061^{*}$ & -15.391 \\
\hline & $(12.804)$ & $(13.217)$ & $(13.454)$ \\
\hline \multirow[t]{2}{*}{ Immigrant pop. (\% prov.) } & 0.016 & 0.026 & -0.025 \\
\hline & $(0.023)$ & $(0.025)$ & $(0.026)$ \\
\hline \multirow[t]{2}{*}{ Constant } & $-11.212^{* *}$ & -9.365 & $-9.640 * *$ \\
\hline & $(5.076)$ & $(6.985)$ & $(3.745)$ \\
\hline \multicolumn{4}{|l|}{ Omitted controls: } \\
\hline - Individual & $\checkmark$ & $\checkmark$ & $\checkmark$ \\
\hline - Regional & $\checkmark$ & $\checkmark$ & $\checkmark$ \\
\hline - Provincial & $\checkmark$ & $\checkmark$ & $\checkmark$ \\
\hline Observations & 3,003 & 3,003 & 3,003 \\
\hline R-squared & 0.051 & 0.039 & 0.043 \\
\hline
\end{tabular}

The table displays the results form OLS regressions of our immigration sentiment and tax burden outcomes on our pessimistic ecnomic information intervention interacted with the respondents' sample income tertile. Omitted individual controls: age, family size, italian born, single. Omitted regional controls: life expectancy. Omitted provincial controls: population.

Robust standard errors, clustered at province level, in parentheses.

$* * * \mathrm{p}<0.01, * * \mathrm{p}<0.05,{ }^{*} \mathrm{p}<0.1$ 
Table D4: OLS regression of immigration sentiments: health dimension

\begin{tabular}{|c|c|c|c|}
\hline \multirow[b]{2}{*}{ VARIABLES } & \multicolumn{3}{|c|}{ Health dimension } \\
\hline & Too many immigrants & Health exp to natives & General tax burden \\
\hline \multirow[t]{2}{*}{ Pessimistic info. } & $0.107^{* *}$ & 0.044 & -0.035 \\
\hline & $(0.051)$ & $(0.049)$ & $(0.055)$ \\
\hline \multirow{2}{*}{ Income tertile $=2$} & $-0.087^{*}$ & $-0.131^{* *}$ & -0.057 \\
\hline & $(0.049)$ & $(0.065)$ & $(0.058)$ \\
\hline \multirow[t]{2}{*}{ Income tertile $=3$} & $-0.177^{* * *}$ & $-0.124^{* *}$ & -0.035 \\
\hline & $(0.058)$ & $(0.057)$ & $(0.075)$ \\
\hline \multirow[t]{2}{*}{ Pessimistic info. $\times$ Income tertile $=2$} & -0.073 & 0.087 & 0.096 \\
\hline & $(0.078)$ & $(0.079)$ & $(0.068)$ \\
\hline \multirow[t]{2}{*}{ Pessimistic info. $\times$ Income tertile $=3$} & -0.101 & -0.011 & -0.094 \\
\hline & $(0.084)$ & $(0.079)$ & $(0.098)$ \\
\hline \multirow[t]{2}{*}{ Unemployed } & 0.031 & -0.015 & 0.067 \\
\hline & $(0.067)$ & $(0.065)$ & $(0.062)$ \\
\hline \multirow[t]{2}{*}{ College } & $-0.217^{* * *}$ & $-0.149 * * *$ & $-0.088^{*}$ \\
\hline & $(0.037)$ & $(0.040)$ & $(0.047)$ \\
\hline \multirow[t]{2}{*}{ Female } & $0.188^{* * *}$ & $0.105^{* * *}$ & -0.027 \\
\hline & $(0.035)$ & $(0.039)$ & $(0.039)$ \\
\hline \multirow[t]{2}{*}{ GDP p.c. } & 0.003 & 0.002 & -0.005 \\
\hline & $(0.008)$ & $(0.007)$ & $(0.011)$ \\
\hline \multirow[t]{2}{*}{ Unemployment (\% 15-64) } & 0.013 & 0.012 & -0.009 \\
\hline & $(0.015)$ & $(0.012)$ & $(0.017)$ \\
\hline \multirow[t]{2}{*}{ C19 } & 1.354 & -7.972 & -4.691 \\
\hline & $(13.852)$ & $(13.832)$ & $(17.948)$ \\
\hline \multirow[t]{2}{*}{ Immigrant pop. (\% prov.) } & -0.015 & 0.021 & -0.001 \\
\hline & $(0.026)$ & $(0.026)$ & $(0.033)$ \\
\hline \multirow[t]{2}{*}{ Constant } & -7.615 & $-11.577^{* * *}$ & -2.206 \\
\hline & $(5.691)$ & $(4.381)$ & $(5.602)$ \\
\hline \multicolumn{4}{|l|}{ Omitted controls: } \\
\hline - Individual & $\checkmark$ & $\checkmark$ & $\checkmark$ \\
\hline - Regional & $\checkmark$ & $\checkmark$ & $\checkmark$ \\
\hline - Provincial & $\checkmark$ & $\checkmark$ & $\checkmark$ \\
\hline Observations & 2,956 & 2,956 & 2,956 \\
\hline R-squared & 0.060 & 0.060 & 0.039 \\
\hline
\end{tabular}

The table displays the results form OLS regressions of our immigration sentiment and tax burden outcomes on our pessimistic health information intervention interacted with the respondents' sample income tertile. Omitted individual controls: age, family size, italian born, single. Omitted regional controls: life expectancy. Omitted provincial controls: population.

Robust standard errors, clustered at province level, in parentheses.

$* * * \mathrm{p}<0.01, * * \mathrm{p}<0.05,{ }^{*} \mathrm{p}<0.1$ 


\section{D.3 Exposure to the virus}

The respondents' degree of exposure to the Covid-19 virus is the result of a principal component analysis of the respondents' answers to whether they were infected themselves, at least one of their family members was, and at least one of their friends, all measured on a scale from 1 to 10. All variables load positively and strongly on a single retained component, as shown in Table D5.

\begin{tabular}{|c|c|c|c|c|c|}
\hline Factor & Eigenvalue & Explained variance & \multicolumn{3}{|c|}{ Rotated factor loadings } \\
\hline & & & Contracted & Cases in family & Cases among friends \\
\hline 1 (retained) & 1.50 & 0.50 & 0.78 & 0.81 & 0.47 \\
\hline 2 & 0.92 & 0.30 & & & \\
\hline 3 & 0.57 & 0.19 & & & \\
\hline
\end{tabular}

Table D5: Factor analysis of measures of individual exposure to the virus.

From Tables D6 and D7 receiving pessimistic economic or health information about the situation in Italy does not interact with the respondents' self-reported degree of direct or indirect exposure to the Covid-19 virus. 
Table D6: OLS regression of immigration sentiments: economic dimension

\begin{tabular}{|c|c|c|c|}
\hline \multirow[b]{2}{*}{ VARIABLES } & \multicolumn{3}{|c|}{$\begin{array}{l}\text { Economic dimension } \\
\end{array}$} \\
\hline & Too many immigrants & Health exp to natives & General tax burden \\
\hline \multirow[t]{2}{*}{ Pessimistic info. } & $0.112^{* * *}$ & $0.101^{* * *}$ & $0.068 * *$ \\
\hline & $(0.035)$ & $(0.031)$ & $(0.032)$ \\
\hline \multirow[t]{2}{*}{ Exposure } & 0.010 & -0.028 & 0.025 \\
\hline & $(0.020)$ & $(0.024)$ & $(0.022)$ \\
\hline \multirow[t]{2}{*}{ Pessimistic info. $\times$ Exposure } & -0.008 & 0.017 & -0.044 \\
\hline & $(0.030)$ & $(0.032)$ & $(0.037)$ \\
\hline \multirow[t]{2}{*}{ Unemployed } & $0.138^{* *}$ & -0.035 & 0.088 \\
\hline & $(0.066)$ & $(0.066)$ & $(0.066)$ \\
\hline \multirow[t]{2}{*}{ College } & $-0.251^{* * *}$ & $-0.188^{* * *}$ & -0.055 \\
\hline & $(0.037)$ & $(0.034)$ & $(0.037)$ \\
\hline \multirow[t]{2}{*}{ Female } & $0.136^{* * *}$ & $0.076^{* *}$ & -0.034 \\
\hline & $(0.034)$ & $(0.035)$ & $(0.033)$ \\
\hline \multirow[t]{2}{*}{ Income tertile $=2$} & -0.074 & $-0.102^{*}$ & 0.029 \\
\hline & $(0.049)$ & $(0.052)$ & $(0.044)$ \\
\hline \multirow[t]{2}{*}{ Income tertile $=3$} & -0.053 & -0.083 & -0.029 \\
\hline & $(0.051)$ & $(0.056)$ & $(0.053)$ \\
\hline \multirow[t]{2}{*}{ GDP p.c. } & 0.003 & 0.001 & $0.013^{*}$ \\
\hline & $(0.007)$ & $(0.007)$ & $(0.007)$ \\
\hline \multirow[t]{2}{*}{ Unemployment (\% 15-64) } & $0.022^{*}$ & $0.025^{* *}$ & $0.031^{* * *}$ \\
\hline & $(0.012)$ & $(0.012)$ & $(0.010)$ \\
\hline \multirow[t]{2}{*}{ C19 } & 5.376 & $25.712^{*}$ & -15.639 \\
\hline & $(12.785)$ & $(13.341)$ & $(13.557)$ \\
\hline \multirow[t]{2}{*}{ Immigrant pop. ( $\%$ prov.) } & 0.015 & 0.025 & -0.024 \\
\hline & $(0.023)$ & $(0.025)$ & $(0.026)$ \\
\hline \multirow[t]{2}{*}{ Constant } & $-11.151^{* *}$ & -9.131 & $-9.496^{* *}$ \\
\hline & $(5.028)$ & $(6.922)$ & $(3.681)$ \\
\hline \multicolumn{4}{|l|}{ Omitted controls: } \\
\hline - Individual & $\checkmark$ & $\checkmark$ & $\checkmark$ \\
\hline - Regional & $\checkmark$ & $\checkmark$ & $\checkmark$ \\
\hline - Provincial & $\checkmark$ & $\checkmark$ & $\checkmark$ \\
\hline Observations & 3,003 & 3,003 & 3,003 \\
\hline R-squared & 0.051 & 0.039 & 0.044 \\
\hline
\end{tabular}

The table displays the results form OLS regressions of our immigration sentiment and tax burden outcomes on our pessimistic economic information intervention interacted with the respondents' sample income tertile. Omitted individual controls: age, family size, italian born, single. Omitted regional controls: life expectancy. Omitted provincial controls: population.

Robust standard errors, clustered at province level, in parentheses.

$* * * \mathrm{p}<0.01, * * \mathrm{p}<0.05,{ }^{*} \mathrm{p}<0.1$ 
Table D7: OLS regression of immigration sentiments: health dimension

\begin{tabular}{|c|c|c|c|}
\hline \multirow[b]{2}{*}{ VARIABLES } & \multicolumn{3}{|c|}{ Health dimension } \\
\hline & Too many immigrants & Health exp to natives & General tax burden \\
\hline \multirow{2}{*}{ Pessimistic info. $=1$} & 0.055 & $0.072^{* *}$ & -0.028 \\
\hline & $(0.039)$ & $(0.035)$ & $(0.040)$ \\
\hline \multirow[t]{2}{*}{ Exposure } & 0.026 & $0.053^{* * *}$ & 0.014 \\
\hline & $(0.023)$ & $(0.019)$ & $(0.028)$ \\
\hline \multirow[t]{2}{*}{ Pessimistic info. $\times$ Exposure } & -0.027 & -0.053 & -0.018 \\
\hline & $(0.036)$ & $(0.035)$ & $(0.040)$ \\
\hline \multirow[t]{2}{*}{ Unemployed } & 0.030 & -0.011 & 0.068 \\
\hline & $(0.067)$ & $(0.066)$ & $(0.062)$ \\
\hline \multirow[t]{2}{*}{ College } & $-0.217^{* * *}$ & $-0.150 * * *$ & $-0.087^{*}$ \\
\hline & $(0.038)$ & $(0.039)$ & $(0.047)$ \\
\hline \multirow[t]{2}{*}{ Female } & $0.186^{* * *}$ & $0.103^{* * *}$ & -0.028 \\
\hline & $(0.035)$ & $(0.039)$ & $(0.040)$ \\
\hline \multirow[t]{2}{*}{ Income tertile $=2$} & $-0.124^{* * *}$ & $-0.092^{* *}$ & -0.011 \\
\hline & $(0.042)$ & $(0.044)$ & $(0.050)$ \\
\hline \multirow{2}{*}{ Income tertile $=3$} & $-0.230 * * *$ & $-0.134^{* * *}$ & -0.085 \\
\hline & $(0.043)$ & $(0.044)$ & $(0.058)$ \\
\hline \multirow[t]{2}{*}{ GDP p.c. } & 0.003 & 0.001 & -0.006 \\
\hline & $(0.008)$ & $(0.007)$ & $(0.011)$ \\
\hline \multirow[t]{2}{*}{ Unemployment (\% 15-64) } & 0.013 & 0.011 & -0.011 \\
\hline & $(0.015)$ & $(0.012)$ & $(0.018)$ \\
\hline \multirow[t]{2}{*}{ C19 } & 0.783 & -8.194 & -3.908 \\
\hline & $(13.645)$ & $(13.745)$ & $(18.097)$ \\
\hline \multirow[t]{2}{*}{ Immigrant pop. ( $\%$ prov.) } & -0.016 & 0.023 & 0.002 \\
\hline & $(0.025)$ & $(0.026)$ & $(0.033)$ \\
\hline \multirow[t]{2}{*}{ Constant } & -7.506 & $-11.246^{* *}$ & -1.955 \\
\hline & $(5.705)$ & $(4.427)$ & $(5.630)$ \\
\hline \multicolumn{4}{|l|}{ Omitted controls: } \\
\hline - Individual & $\checkmark$ & $\checkmark$ & $\checkmark$ \\
\hline - Regional & $\checkmark$ & $\checkmark$ & $\checkmark$ \\
\hline - Provincial & $\checkmark$ & $\checkmark$ & $\checkmark$ \\
\hline Observations & 2,956 & 2,956 & 2,956 \\
\hline R-squared & 0.060 & 0.061 & 0.038 \\
\hline
\end{tabular}

The table displays the results form OLS regressions of our immigration sentiment and tax burden outcomes on our pessimistic health information intervention interacted with the respondents' sample income tertile. Omitted individual controls: age, family size, italian born, single. Omitted regional controls: life expectancy. Omitted provincial controls: population.

Robust standard errors, clustered at province level, in parentheses.

$* * * \mathrm{p}<0.01, * * \mathrm{p}<0.05,{ }^{*} \mathrm{p}<0.1$ 


\section{E Multiple hypothesis testing}

We now report p-values for the effect of receiving pessimistic information in the economic and health dimension presented in Section 5, corrected for multiple hypothesis testing using the method discussed in List et al. (2019) and implemented by Barsbai et al. (2020).

We present two sets of corrected p-values, one for each of the economic and health dimensions in Tables E8 and E9 respectively, alongside the uncorrected p-values for comparison. The uncorrected p-values can be directly interpreted when interest is in the impact of our intervention on a specific outcome (e.g. the effect of pessimist economic information on general immigration sentiment).

Immediately next to the uncorrected p-values, we report the p-values corrected for the simultaneous estimation of all the equations for which we have presented results in Section 5. We moreover include analyses on outcome variables measuring demand for various types of tax financed welfare intervention and perceptions of one's own tax burden, which were not discussed in this article. Even after performing such a restrictive and conservative correction, our core results on immigration sentiment in the economic dimension remain well within conventional significance levels (Table E8).

Next, we report the p-values corrected for the simultaneous estimation of multiple equations within each group of outcomes measuring similar attitudes, i.e. immigration sentiments, perception of the tax burden, demand for tax financed welfare support and voting intentions. These corrections account for the potential correlation between outcomes (hence, between hypotheses), which is critical a number of dependent variables measure analogous expressions of a same underlying attitude. In our case, two variables measure different expressions of immigration attitudes, two measure different expressions of tax burden perceptions, and so on. These p-values are relevant for those with an interest in the broader outcome categories (e.g., in keeping with the previous example, the impact of the pessimistic eonomic information on immigration sentiment). Our core estimates on immigration sentiment and tax burden perceptions survive these corrections. 
Table E8: Correction for multiple hypotheses: economic dimension

\begin{tabular}{|c|c|c|c|c|c|}
\hline & $\begin{array}{r}\text { Uncorrected } \\
\text { p-values }\end{array}$ & & $\begin{array}{c}\text { Corrected } \\
\text { p-values }\end{array}$ & & \\
\hline Too many immigrants & $.0023^{* * *}$ & $.0185^{* *}$ & $.002 * * *$ & & \\
\hline Health ex. to natives & $.0019^{* * *}$ & $.0169^{* *}$ & $.001^{* * *}$ & & \\
\hline General tax too high & $.0351^{* *}$ & .2249 & $.065^{*}$ & & \\
\hline Self tax too high & .6366 & .9268 & .637 & & \\
\hline +Taxes - Poverty & .4421 & .9035 & & .706 & \\
\hline +Taxes + Health exp. & .7735 & .7735 & & .773 & \\
\hline +Taxes + Unemployed welf. & .4163 & .9103 & & .750 & \\
\hline+ Taxes + Pensions & .7372 & .8848 & & .884 & \\
\hline Incumbent voting & .606 & .9602 & & & .606 \\
\hline Populist voting & $.0729 *$ & .3662 & & & .175 \\
\hline Anti-immigration voting & $.0849^{*}$ & .3711 & & & .141 \\
\hline
\end{tabular}

Table E9: Correction for multiple hypotheses: health dimension

\begin{tabular}{lrrrrr}
\hline & $\begin{array}{r}\text { Uncorrected } \\
\text { p-values }\end{array}$ & \multicolumn{4}{c}{$\begin{array}{c}\text { Corrected } \\
\text { p-values }\end{array}$} \\
Too many immigrants & .1741 & .6267 & .1741 & & \\
Health ex. to natives & $.0583^{*}$ & .3618 & $.091^{*}$ & & \\
General tax too high & .4927 & .9506 & & .4927 & \\
Self tax too high & .1135 & .5147 & .1914 & & \\
+ Taxes - Poverty & .6585 & .9715 & & .9169 & \\
+ Taxes + Health exp. & .8211 & .9914 & & .9472 & \\
+ Taxes + Unemployed welf. & .8353 & .9719 & & .8353 & \\
+ Taxes + Pensions & .5895 & .9608 & & .9029 & \\
Incumbent voting & .109 & .5415 & & & .2367 \\
Populist voting & .444 & .9421 & & & .6074 \\
Anti-immigration voting & .9808 & .9808 & & & .9808 \\
\hline
\end{tabular}

Asterisks denote conventional significance levels. 